\title{
MicroRNAs as regulators of cisplatin-resistance in non-small cell lung carcinomas
}

\author{
Irina Fadejeva ${ }^{1}$, Horst Olschewski ${ }^{1,2}$ and Andelko Hrzenjak ${ }^{1,2}$ \\ ${ }^{1}$ Division of Pulmonology, Department of Internal Medicine, Medical University of Graz, Graz, Austria \\ ${ }^{2}$ Ludwig Boltzmann Institute of Lung Vascular Research, Medical University of Graz, Graz, Austria \\ Correspondence to: Andelko Hrzenjak, email: andelko.hrzenjak@medunigraz.at
}

Keywords: cisplatin resistance, microRNA, chemotherapy, NSCLC, hypoxia

Received: September 24, 2017 Accepted: November 15, $2017 \quad$ Published: December 05, 2017

Copyright: Fadejeva et al. This is an open-access article distributed under the terms of the Creative Commons Attribution License 3.0 (CC BY 3.0), which permits unrestricted use, distribution, and reproduction in any medium, provided the original author and source are credited.

\section{ABSTRACT}

\begin{abstract}
With more than $\mathbf{8 0} \%$ of all diagnosed lung cancer cases, non-small cell lung cancer (NSCLC) remains the leading cause of cancer death worldwide. Exact diagnosis is mostly very late and advanced-stage NSCLCs are inoperable at admission. Tailored therapies with tyrosine kinase inhibitors are only available for a minority of patients. Thus, chemotherapy is often the treatment of choice. As first-line chemotherapy for NSCLCs, platinum-based substances (e.g. cisplatin, CDDP) are mainly used. Unfortunately, the positive effects of CDDP are frequently diminished due to development of drug resistance and negative influence of microenvironmental factors like hypoxia. MicroRNAs (miRNAs) are small, non-coding molecules involved in the regulation of gene expression and modification of biological processes like cell proliferation, apoptosis and cell response to chemotherapeutics. Expression of miRNAs is often deregulated in lung cancer compared to corresponding non-malignant tissue. In this review we summarize the present knowledge about the effects of miRNAs on CDDP-resistance in NSCLCs. Further, we focus on miRNAs deregulated by hypoxia, which is an important factor in the development of CDDP-resistance in NSCLCs. This review will contribute to the general understanding of miRNA-regulated biological processes in NSCLC, with special focus on the role of miRNA in CDDP-resistance.
\end{abstract}

\section{INTRODUCTION}

Lung cancer is a very common cancer worldwide [1]. There are different types of lung cancer, that are diagnosed by histology and cytology [2]. The final diagnosis should be determined multidisciplinary by analyzing morphology and genetic changes of the cancerous tissue. Classification of lung cancer includes two large histological groups: nonsmall cell lung cancer (NSCLC) accounting for approx. $85 \%$, and small cell lung cancer (SCLC) accounting for approx. $15 \%$ of all lung cancers [3]. NSCLC are classified into three different subtypes: adenocarcinoma (ADC), squamous-cell carcinoma (SCC) and large-cell carcinoma (LCC) [3-5]. Adenocarcinoma is the most frequent type of lung cancer [6]. Mortality is very high, with 5-year survival rates around $15-20 \%$. This is due to both poor tools for early diagnosis where the disease is still operable, and poor tools for therapy, once the tumor is inoperable. The therapy for NSCLC patients frequently includes platinumbased chemotherapeutics like cisplatin (cisdiaminedichloroplatinum, CDDP) or carboplatin. It is well known that continuous and/or multiple administrations frequently result in the development of drug resistance, which often leads to treatment failure.

Accumulating data indicate that CDDP-resistance is inter alia modified by microRNAs (miRNAs). MiRNAs are small, endogenous, noncoding RNA molecules that consist of about 18-23 nucleotides and have influence on posttranscriptional regulation of gene expression, thereby acting as tumor suppressor or as oncogenes [7]. Evolutionary conserved, miRNAs bind to the 3 '-untranslated region (3'UTR) of target mRNA, leading to translational repression and mRNA degradation. MiRNAs play a vital role in different cellular processes in non-malignant and in tumor 
cells, such as cell growth, differentiation, motility and apoptosis. MiRNAs in cancer are involved in different processes of tumorigenesis like tumor proliferation, migration, angiogenesis, apoptosis, drug transport, DNA repair, etc. [8]. MiRNAs are involved in the development of a variety of tumors, such as leukemia, neuroblastoma, pituitary adenoma, breast cancer, thyroid cancer, hepatocarcinoma, colorectal cancer, and lung cancer. The up- or downregulation of miRNAs in different tumor tissues has been shown, with most of the miRNA targets located in regions of tumor-related genes, fragile sites, loss of heterozygosity, and amplified regions. For example miR-21 is overexpressed in many human malignancies, including NSCLC [9].

The molecular and genetic basis of sensitivity and resistance to chemotherapy is complex, involving multiple processes such as regulation of cell cycle, apoptosis, drug transport, drug metabolism, DNA repair, etc. The molecular mechanisms of CDDP-resistance have not been fully understood and may include: decreased accumulation of CDDP, increased detoxification systems (such as GSH, GSTP1, and metallothionein), decreased DNA damage, and/or increased DNA repair. CDDP-resistance in tumor cells allows the cells to escape the cytotoxic effects of the drug and to overcome apoptosis [10]. In lung cancer, it has been shown that miRNAs play an important role in the development of chemosensitivity and chemoresistance [11]. In tumor cells and tumor tissues these regulatory mechanism are complementary and can either enhance or block each other. This review article will describe the role of miRNAs in CDDP-resistance of NSCLC cells.

\section{MiRNAs and cell proliferation in CDDP- resistant NSCLCs}

One single miRNA can regulate different target genes, and one target gene can be regulated by different miRNAs, making the assignment of one miRNA to a particular pathway or to a molecular mechanism very challenging. This is especially the case for miRNAs and their target molecules involved in cell proliferation and apoptosis, mechanisms of extraordinary importance for tumor development and progression. Figure 1 summarizes correlations between different miRNAs and their target genes known to be involved in resistance of NSCLC cells to CDDP. It clearly indicates that many miRNAs influence different target genes and are, therefore, players in different cellular processes. In context of the CDDPresistance in NSCLC cells, miR-21 appears as very prominent. MiR-21 influences target genes involved in apoptotic pathways, cell proliferation, migration, invasion, and metastasis development. Among target genes regulated by different miRNAs, PTEN is particularly prominent, and appears to be involved in the regulation of CDDP-resistance in NSCLC cells and tumors. These regulatory mechanisms and their possible correlations will be discussed in more detail in the following paragraphs.
Tumor progression is dependent on different cellular processes, including cell proliferation and apoptosis. MiRNA-216a regulates NSCLC progression by acting as a tumor suppressor. Wang et al. analyzed 119 NSCLC specimens and detected significant downregulation of miR-216a compared to adjacent lung tissue [12]. Furthermore, this down-regulation was associated with the tumor stage and the development of metastasis in NSCLC patients. By means of different experimental approaches it was shown that miR-216a suppresses cell growth by affecting cell proliferation and apoptosis, both in vitro and in vivo. Primary tumors from NSCLC patients with metastasis showed significantly decreased miR-216a expression in comparison to patients without metastasis. As main target-genes eIF4B and ZEB1, two oncogenes playing an important role in chemoresistance, were identified. This was further supported by marked increase of the sensitivity of NSCLC cells to CDDP treatment due to miR-216a overexpression. Surprisingly, in liver cancer not eIF4B or ZEB1, but PTEN and SMAD7 were the main targets of miR-216a. These discrepancies might be based on different algorithms used for target gene prediction, or more probably, they indicate that the same miRNA targets different genes in different tissues.

MiR-630 inhibits activation of p53, the master regulator of CDDP-induced cell death, and blocks the early DNA damage response in lung cancer cells [13]. Furthermore, miRNA-630 also reduces pro-apoptotic pathways regulated by p53. Pre-miR-630-transfected cells were arrested in the G0-G1 phase, which correlated with increased levels of the p27Kip1 protein. P27Kip1 is a cell cycle inhibitor that regulates cell cycle progression at the G1 phase due to interaction with cyclin-CDK2 and -CDK4. Interestingly, not only the proliferation rate, but also the sensitivity of cells overexpressing pre-miR-630 to CDDP was markedly reduced. This suggests that miR630 protects NSCLC cells against CDDP by regulating the same signaling pathway as p53.

MiR-34a was significantly up-regulated in CDDPtreated NSCLC tumor tissues and NSCLC cell lines, indicating that CDDP induces miR-34a expression. Expression of miR-34a is regulated by p53 and miR34 a regulates apoptosis, cell cycle and differentiation $[14,15]$. MiR-34a expression was significantly downregulated in NSCLC tumor tissue in comparison to adjacent non-malignant lung tissue. Interestingly, miR-34a level in serum of CDDP-sensitive patients was higher in comparison to patients with CDDP-resistance. The MYCN gene, coding for $\mathrm{N}$-myc proto-oncogene protein is a direct functional target of miR-34a. Altogether, these data indicate that miR-34a enhances the sensitivity of NSCLC cells to CDDP via the $\mathrm{p} 53 / \mathrm{miR}-34 \mathrm{a} / \mathrm{MYCN}$ axis.

Different studies suggested an up-regulation of miR-92b in NSCLC tissue and cell lines, compared to adjacent lung tissue. Overexpression of miR-92b promoted A549/CDDP cell growth and inhibited 

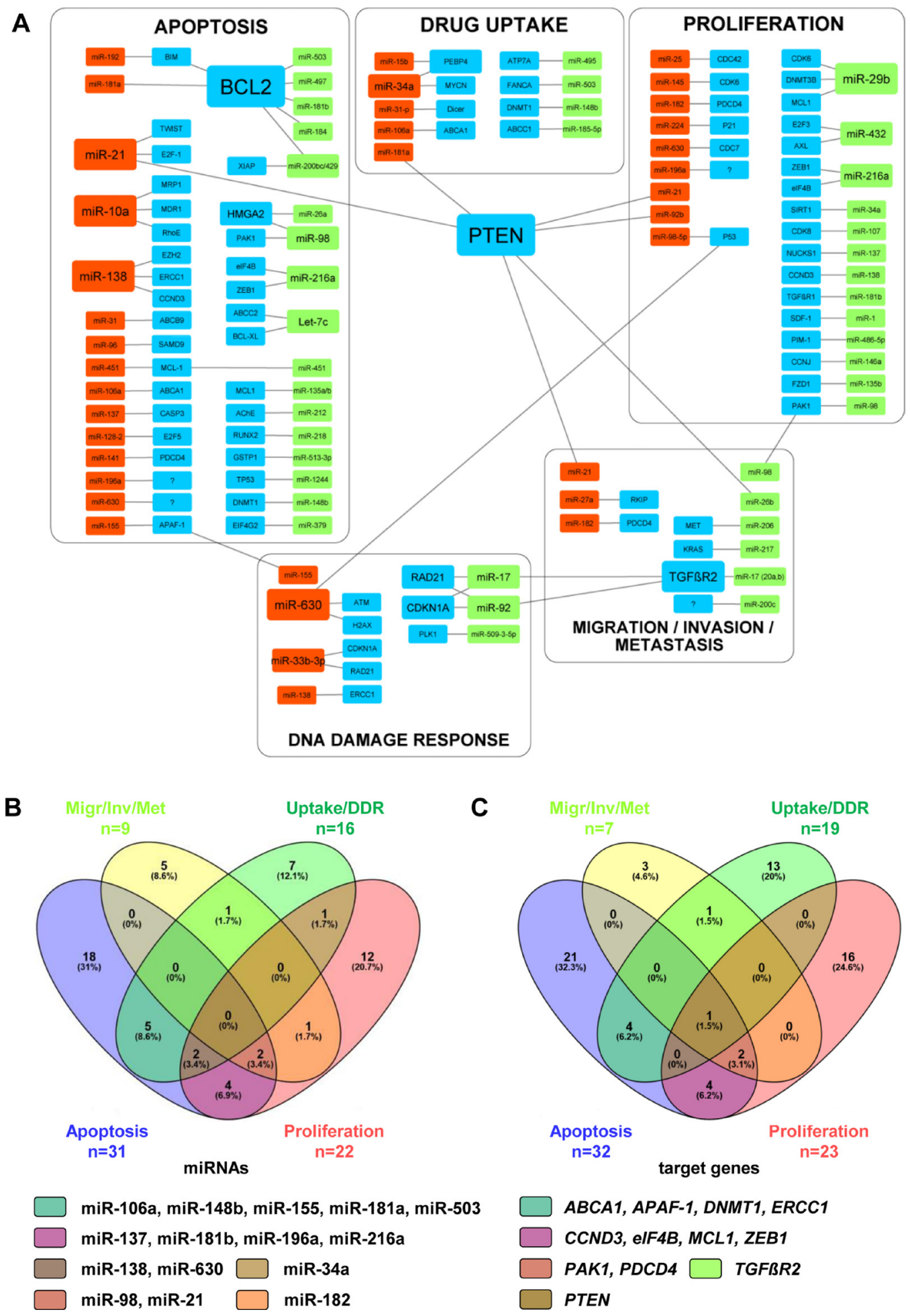

Figure 1: Correlations between miRNAs involved in resistance of NSCLC cells to CDDP. (A) Different miRNAs and their target genes listed in Tables 1-3 were graphically put in correlation by using the Cytoscape software (ver. 3.4.0). Size of rectangular shapes correlates to the number of interactions between miRNAs and target genes. Red, up-regulated miRNAs; green, down-regulated miRNAs; blue, target genes. (B, C) Venn diagrams showing correlations between the miRNAs $(n=78)$ within particular pathways (B) and between target genes $(n=81)$ assigned to particular pathways $(\mathbf{C})$. All MiRNAs and target genes shown in Venn diagrams are named in particular subgroups shown in Figure 1A. Venn diagrams were generated by publically available Venny-tool (http://bioinfogp.cnb.csic.es/ tools/venny/). The group Apoptosis is shown in violet, group Proliferation in pink, group Migration/Invasion/Metastasis (Migr/Inv/Met) in yellow, and group Drug uptake/DNA repair (Uptake/DDR) in green. For each particular subgroup, the number and percentage of miRNAs or target genes are indicated. MiRNAs and target genes detected as multiplayers in different cell processes are listed accordingly to the color code of Venn diagrams. 
Table 1: MiRNAs involved in CDDP-resistance of NSCLC cells mainly assigned to cell proliferation and cell cycle pathways

\begin{tabular}{|c|c|c|c|c|c|}
\hline miRNA & Targets & Cells / Tissue & Expression & Function & Reference \\
\hline $\operatorname{miR}-1$ & SDF-1 & $\begin{array}{l}\text { Cancer-associated fibroblasts } \\
\text { (CAFs) }\end{array}$ & down & $\begin{array}{c}\text { Negatively regulates SDF-1 and influence CDDP- } \\
\text { resistance in CAFs }\end{array}$ & [106] \\
\hline $\mathrm{mR}-21$ & PTEN & Serum, NSCLC cells & up & Correlates with TNM stage, increases growth & {$[9]$} \\
\hline $\operatorname{miR}-25$ & $\mathrm{CDC} 42$ & NSCLC tissue, A549/PAR & up & Increases proliferation, decreases CDDP-sensitivity & {$[24]$} \\
\hline $\operatorname{miR}-29 b$ & $\begin{array}{c}\text { CDK6, } \\
\text { DNMT3B, } \\
\text { MCL1 }\end{array}$ & A549 cells & down & Reduces expression of CDK6, inhibits cell growth & {$[107]$} \\
\hline $\operatorname{miR}-34 a$ & SIRT1 & NSCLC tissue, A549/PAR & down & Sensitizes NSCLC cells to CDDP & {$[108]$} \\
\hline $\operatorname{miR}-92 b$ & PTEN & NSCLC tissue, A549/PAR & up & $\begin{array}{l}\text { Oncogene, inhibits apoptosis, induces cell growth and } \\
\text { resistance to CDDP }\end{array}$ & $(46)$ \\
\hline miR-98 & PAK1 & NSCLC tissue, A549/PAR & down & Inversely regulates $\mathrm{PAK} 1$, inhibits proliferation & $(87)$ \\
\hline $\operatorname{miR}-98-5 p$ & P53 & NSCLC cells & up & $\begin{array}{l}\text { Inhibition of miR-98-5p increases p53 expression and } \\
\text { CDDP efficacy }\end{array}$ & [109] \\
\hline miR-107 & CDK8 & A549/PAR & down & $\begin{array}{l}\text { Neg. regulates CDK8, inhibits cell growth, has a key role } \\
\text { in CDDP-resistance }\end{array}$ & {$[21]$} \\
\hline miR-135b & FZD1 & A549/CDDP & down & $\begin{array}{l}\text { Suppresses CDDP-resistance in NSCLC by targeting } \\
\text { FZD1 }\end{array}$ & {$[110]$} \\
\hline miR-137 & NUCKS1 & NSCLC tissue, A549/CDDP & down & $\begin{array}{l}\text { Down-regulation promotes cell growth, migration and } \\
\text { G1/S transition }\end{array}$ & [111] \\
\hline $\operatorname{miR}-138$ & CCND3 & NSCLC cells & down & $\begin{array}{l}\text { Negatively regulates CDDP-resistance, influences cell } \\
\text { migration }\end{array}$ & {$[40]$} \\
\hline miR-145 & CDK6 & NSCLC cells/CDDP & up & $\begin{array}{l}\text { Indirectly influences DCK6 expression and CDDP- } \\
\text { resistance }\end{array}$ & {$[22]$} \\
\hline $\operatorname{miR}-146 a$ & $\mathrm{CCNJ}$ & A549/CDDP & down & $\begin{array}{l}\text { Increases the sensitivity to CDDP, targets drug-resistance- } \\
\text { associated proteins }\end{array}$ & {$[112,113]$} \\
\hline miR-181b & TGFßR1 & A549/CDDP & down & $\begin{array}{l}\text { Influence CDDP-resistance by targeting TGFßR1/Smad } \\
\text { pathway }\end{array}$ & [114] \\
\hline $\operatorname{miR}-182$ & PDCD4 & A549/PAR & up & $\begin{array}{l}\text { Inversely regulates PDCD4 expression, influences CDDP- } \\
\text { resistance }\end{array}$ & [84] \\
\hline miR-196a & n. d. & A549/CDDP & up & $\begin{array}{l}\text { Regulates MDR1, MRP1, ERCC1, surviving, Bcl2 and } \\
\text { RhoE }\end{array}$ & [115] \\
\hline miR-216a & $\begin{array}{l}\text { eIF4B, } \\
\text { ZEB1 }\end{array}$ & NSCLC tissue & down & $\begin{array}{l}\text { Tumor suppressor miRNA, influences CDDP-induced } \\
\text { apoptosis }\end{array}$ & [12] \\
\hline $\operatorname{miR}-224$ & $\begin{array}{l}\text { P21(WAF1/ } \\
\text { CIP1) }\end{array}$ & A549/CDDP & up & $\begin{array}{l}\text { Promotes CDDP-resistance via regulating G1/S transition } \\
\text { and apoptosis }\end{array}$ & {$[116]$} \\
\hline $\operatorname{miR}-432$ & E2F3, AXL & NSCLC tissue, NSCLC cells & down & $\begin{array}{l}\text { Negatively correlates with E2F3 and AXL and influence } \\
\text { CDDP-resistance }\end{array}$ & {$[117]$} \\
\hline $\operatorname{miR}-486-5 p$ & PIM-1 & NSCLC cells, NSCLC tissue & down & $\begin{array}{l}\text { Negatively regulates Pim-1 and decreases sensitivity to } \\
\text { CDDP }\end{array}$ & [118] \\
\hline miR-630 & $\mathrm{CDC} 7$ & NSCLC cells & up & $\begin{array}{l}\text { Has a bimodal role in regulation of DNA-damage and } \\
\text { apoptosis }\end{array}$ & [23] \\
\hline
\end{tabular}

n. d., not defined; Expression = expression in CDDP-resistant cells or NSCLC tissue in comparison to sensitive cells or non-malignant lung tissue.

apoptosis, thereby inducing CDDP-resistance by directly targeting the tumor suppressor gene PTEN [16]. Inhibition of miR-92b had the opposite effects. In another study, almost identical effects have been described, however, the expression of miR-92b in NSCLC tissues was negatively correlated with the tumor suppressor gene RECK which is frequently down-regulated in tumors [17]. Together, all these results suggest that miR-92b acts as an oncogene in the NSCLC.

Overexpression of polo-like kinase 1 (PLK1) is a negative prognostic factor for NSCLC patients and patients suffering from some other solid tumors, like esophageal carcinoma, head and neck tumors and melanoma [18]. PLK1 is known as a DNA-damage checkpoint modulator that maintains genomic stability. PLK1 expression is correlated to cancer aggressiveness, based on fast growth of cancer cells [19]. In human lung cancer A549 cells miR-509-3-5p downregulates PLK1 expression by targeting PLK1 3'-UTR and acting as a cancer suppressor [20]. Moreover, PLK1 downregulation upon overexpression of miR-509-3-5p in A549 cells results in $\mathrm{G} 2 / \mathrm{M}$ arrest and aberrant mitosis rate [20]. 
Uncontrolled cell division is a typical feature of cancer cells. Cell cycle is regulated by different proteins and members of the cyclin-dependent protein kinase (CDK) family, known to be relevant regulatory factors in cell cycle progression. One of these proteins, CDK8, is a target of miR-107 in NSCLC cells. Down-regulation of CDK8 in NSCLC cell lines is associated with enhanced sensitivity to CDDP. This suggests that miR-107 takes part in chemotherapy resistance by negative regulation of CDK8, and might be used to predict a NSCLC patient's response to chemotherapy [21]. Another member of the CDK family, CDK6, is a target of miR-145 and downregulation of CDK6 is positively correlated with CDDP-resistance in NSCLC cells [22]. These findings might be of great importance, indicating that agents which suppress CDK6 should not be used during CDDP therapy.

It was shown that CDC7 (cell division cycle 7-related protein kinase), a protein involved in the cell cycle regulation, acts as a target of miR-630, which binds to four binding sites in CDC7 3'-UTR. MiR-630 inhibits the expression of $\mathrm{CDC} 7$, thereby blocking the initiation of DNA synthesis, inducing the G1 arrest, and promoting apoptosis. Interestingly, miR-630 can also reduce apoptosis by blocking other apoptotic modulators such as DDIT4, PARP3 and EP300. Altogether, these findings suggest the bimodal role of miR-630 in the regulation of apoptosis and CDCP-mediated resistance in NSCLC cells [23]. CDC42 is a target of miR-25, taking part in cell proliferation and CDDP-resistance development. Downregulation of miR-25 inhibits proliferation of NSCLC cells, promotes G1 arrest and enhances CDDP-sensitivity via downregulation of CDC42 in vitro. In vivo experiments showed that downregulation of miR-25 reduces tumor growth rate [24].

MiRNAs involved in CDDP-resistance of NSCLC cells which are mainly assigned to cell proliferation and cell cycle pathways are summarized in Table 1.

\section{MiRNAs and apoptosis in CDDP-resistant NSCLCs}

MiRNAs can influence different cell events like differentiation, proliferation, metabolism, growth, and cell death [25]. Mechanisms of the DNA damage and cell apoptosis are closely connected. DNA damage activates the stimulation of checkpoint mechanisms and leads to DNA repair or to cell death by apoptosis [26]. Different studies suggested that miRNAs control cell cycle by activating or inhibiting different proteins involved in a DNA damage response. Members of the BCL-2 family are between the most frequently described target molecules of different miRNAs concerning apoptosis-related CDDP-resistance in NSCLC cells (for summary see Fig. 1A). MiRNAs involved in CDDP-resistance of NSCLC cells, which are mainly assigned to apoptosis pathways, are summarized in
Table 2. Many of these miRNAs have different target genes. However, for more clarity, only target genes proven to be involved in CDDP-resistance in NSCLCs are listed here.

Up-regulation of Bim, an essential component of the electron transport chain, leads to cytochrome-c release from mitochondria and, consequently, to activation of the mitochondrial apoptosis pathway. Accordingly, posttranslational down-regulation of Bim by miR-192 leads to inhibition of apoptosis and to CDDP-resistance in lung adenocarcinoma cells [27, 28]. Furthermore, miR192 directly targets Bcl-2, thereby influencing apoptosis and resistance of A549 cells in response to cisplatin and gemcitabine, a therapy combination frequently used for NSCLC [29]. Down-regulation of miR-184, which is regulated by $\mathrm{E} 6$ oncoprotein, can also be involved in the development of CDDP resistance in NSCLC cells. This supposes that down-regulation of miR-184 may play a role in CDDP resistance by increasing the Bcl-2 expression and thus influencing apoptosis [30]. In NSCLC tissues and cell lines, miR-497 targets different genes like vascular endothelial growth factor A (VEGF-A) [31], yesassociated protein 1 (YAP1) [32], cyclin E1 (CCNE1) [33], hepatoma-derived growth factor (HDGF) [34], and Bcl-2 [35]. However, only Bcl-2 repression by miR-497 was involved in the modulation of CDDP-resistance in NSCLC cells [35].

Bcl-XL is an antiapoptotic protein, shown to be directly deregulated by let-7c. The role of let-7c in development of CDDP-resistance and -sensitivity in NSCLC was investigated by Zhan et al. They showed that let-7c modulates the CDDP-response by targeting ABCC2 and Bcl-XL. The sensitivity of A549/CDDP cells to CDDP was increased upon down-regulation of let-7c [36]. In lung cancer tissue, significantly higher miR-155 expression was detected compared to adjacent non-malignant lung tissue [37]. Apaf-1, a protein that stimulates caspase-9 and activates apoptosis, also can act as a target of miR-155, and up-regulation of miR-155 inhibits the sensitivity of NSCLC cells to CDDP by modulating the DNA damage response (DDR) and apoptosis. After CDDP treatment of miR-155-silenced A549 cells the Apaf-1 protein, but not the Apaf-1 mRNA, was highly elevated. Both the miR-155-silencing and Apaf-1 overexpression markedly increased the sensitivity of A549 cells to CDDP, and this was correlated with increased apoptosis and DNA damage. MiR-155 in NSCLC tissue compared to paracancerous and non-malignant lung tissue expression is significantly increased [37]. Down-regulation of miR-155 increased the sensitivity to CDDP by targeting apoptotic protease activating factor 1 (Apaf-1). Down-regulated miR-155 correlated with high levels of the Apaf-1, an activator of cell apoptosis. This suggests that miR-155 might play a role in the NSCLC carcinogenesis and influence chemoresistance by induction of apoptosis and DDR.

Many studies have examined the expression of miR-138 in NSCLC and its influence on CDDP- 
Table 2: MiRNAs involved in CDDP-resistance of NSCLC cells mainly assigned to apoptosis pathway

\begin{tabular}{|c|c|c|c|c|c|}
\hline miRNA & Targets & Cells / Tissue & Expression & Function & Reference \\
\hline miR-10a & $\begin{array}{l}\text { RhoE, MDR1, } \\
\text { MRP1 }\end{array}$ & A549/CDDP & up & Inhibits apoptosis, enhances drug efflux & [62] \\
\hline $\operatorname{miR}-21$ & $\begin{array}{l}\text { E2F-1, TWIST, } \\
\text { PTEN }\end{array}$ & $\begin{array}{l}\text { NSCLC tissue, NSCLC cells, } \\
\text { A549/CDDP }\end{array}$ & up & $\begin{array}{c}\text { Inhibits apoptosis, blocks the cell cycle, increases } \\
\text { CDDP-resistance }\end{array}$ & $\begin{array}{l}{[54,119,} \\
120]\end{array}$ \\
\hline miR-26a & HMGA2 & A549/CDDP & down & Regulates E2F1-Akt pathway & {$[121]$} \\
\hline miR-31 & ABCB9 & $\begin{array}{l}\text { CDDP-resistant NSCLC } \\
\text { cells }\end{array}$ & up & Anti-apoptotic effects via $\mathrm{ABCB} 9$ inhibition & [67] \\
\hline miR-96 & SAMD9 & NSCLC tissue, NSCLC cells & up & $\begin{array}{c}\text { Down-regulates SAMD9 expression, decreases } \\
\text { apoptosis }\end{array}$ & [64] \\
\hline miR-98 & HMGA2, PAK1 & $\begin{array}{l}\text { A549/CDDP, NSCLC tissue, } \\
\text { A549/PAR }\end{array}$ & down & $\begin{array}{l}\text { Modulates apoptosis via HMGA2, inversely regulates } \\
\text { PAK1, inhibits apoptosis }\end{array}$ & {$[50,51]$} \\
\hline miR-106a & ABCA1 & A549/CDDP & up & Represses apoptosis, decreases CDDP-uptake & [68] \\
\hline miR-128-2 & $\mathrm{E} 2 \mathrm{~F} 5$ & NSCLC cells & up & Inhibits apoptosis, increases resistance to CDDP & [61] \\
\hline $\mathrm{miR}-135 \mathrm{a} / \mathrm{b}$ & MCL1 & A549/CDDP & down & $\begin{array}{l}\text { Modulates apoptosis via MCL1, overexpression } \\
\text { sensitizes A549/CDDP }\end{array}$ & [49] \\
\hline miR-137 & CASP3 & $\begin{array}{l}\text { NSCLC cells overexpressing } \\
\text { miR-137 }\end{array}$ & up & Decreases CASP3 expression and cell death & {$[122]$} \\
\hline $\operatorname{miR}-138$ & $\begin{array}{l}\text { ERCC1, EZH2, } \\
\quad \text { CCND3 }\end{array}$ & A549/CDDP & up & Increases sensitivity to CDDP and apoptosis & {$[38-40]$} \\
\hline miR-141 & PDCD4 & A549/CDDP vs. A549/PAR & up & $\begin{array}{l}\text { Contributes to CDDP-resistance by suppressing } \\
\text { PDCD4 }\end{array}$ & [65] \\
\hline $\operatorname{miR}-148 b$ & DNMT1 & A549/CDDP, SPC-A1/CDDP & down & Influence CDDP-sensitivity, cell viability and apoptosis & [57] \\
\hline miR-155 & APAF-1 & NSCLC tissue, A549/PAR & up & $\begin{array}{l}\text { Inhibits sensitivity to CDDP via negative regulation of } \\
\text { Apaf-1 }\end{array}$ & [37] \\
\hline miR-181a & n. d. & CDDP- treated A549/PAR & up & Enhances CDDP-triggered mitochondrial apoptosis & [13] \\
\hline $\operatorname{miR}-181 b$ & BCL2 & A549/CDDP & down & $\begin{array}{l}\text { Modulation of CDDP-induced apoptosis via targeting } \\
\text { BCL2 }\end{array}$ & [123] \\
\hline miR-184 & BCL2 & NSCLC tissue & down & $\begin{array}{c}\text { Decrease of miR-184 by E6 predicts unfavorable } \\
\text { response to CDDP }\end{array}$ & [30] \\
\hline miR-192 & BIM, BCL2 & A549/PAR, A549/CDDP & up & Inhibits apoptosis via Bcl2, induces CDDP-resistance & {$[28,29]$} \\
\hline miR-196a & n. d. & NSCLC tissue, NSCLC cells & up & Increases CDDP-resistance by inhibiting apoptosis & [124] \\
\hline $\begin{array}{l}\mathrm{miR}- \\
200 \mathrm{bc} / 429 \mathrm{cl}\end{array}$ & BCL2, XIAP & A549/CDDP & down & $\begin{array}{l}\text { Inversely regulates BCL2/XIAP expression and } \\
\text { apoptosis }\end{array}$ & {$[125]$} \\
\hline $\operatorname{miR}-212$ & $\mathrm{AChE}$ & CDDP-treated A549/PAR & down & Anti-apoptotic effects through $\mathrm{AChE}$ repression & {$[60]$} \\
\hline miR-216a & eIF4B, ZEB1 & NSCLC tissue & down & $\begin{array}{l}\text { Suppresses NSCLC growth and metastasis, enhances } \\
\text { apoptosis }\end{array}$ & [12] \\
\hline $\operatorname{miR}-218$ & RUNX2 & NSCLC tissue, NSCLC cells & down & Increases resistance to CDDP via targeting RUNX2 & [63] \\
\hline $\operatorname{miR}-379$ & EIF4G & NSCLC tissue, NSCLC cells & down & $\begin{array}{c}\text { Tumor suppressor, influences CDDP-induced apoptosis } \\
\text { by targeting EIF4G }\end{array}$ & {$[66]$} \\
\hline $\operatorname{miR}-451$ & MCL-1 & $\begin{array}{l}\text { NSCLC tissue, A549/PAR, } \\
\text { A549/CDDP }\end{array}$ & up / down & $\begin{array}{c}\text { Tumor suppressor, inhibits growth and apoptosis by } \\
\text { inactivating Akt pathway }\end{array}$ & {$[47,48]$} \\
\hline $\operatorname{miR}-497$ & BCL2 & A549/CDDP & down & $\begin{array}{l}\text { Modulation of CDDP-induced apoptosis via targeting } \\
\text { BCL2 }\end{array}$ & [35] \\
\hline miR-503 & BCL2 & A549/CDDP & down & Increases resistance to CDDP via targeting BCL2 & [55] \\
\hline miR-513-3p & GSTP1 & A549/CDDP & down & Enhances CDDP-induced apoptosis & {$[126]$} \\
\hline miR-630 & n. d. & CDDP- treated A549/PAR & up & Reduces CDDP-triggered mitochondrial apoptosis & [13] \\
\hline $\operatorname{miR}-1244$ & TP53 & A549/CDDP, A549/PAR & down & Reduces cell proliferation, survival and invasion & [83] \\
\hline Let-7c & $\begin{array}{l}\mathrm{ABCC} 2, \mathrm{BCL}- \\
\mathrm{XL}\end{array}$ & A549/CDDP & down & $\begin{array}{l}\text { Modulates CDDP-response by targeting } \mathrm{ABCC} 2 \text { and } \\
\text { BCL-XL }\end{array}$ & {$[36]$} \\
\hline
\end{tabular}

cl., cluster; n. d., not defined; Expression = expression in CDDP-resistant cells or NSCLC tissue in comparison to sensitive cells or non-malignant lung tissue. 
resistance. Upregulated miR-138 increased the sensitivity to CDDP by inducing apoptosis [38]. In A549/CDDP cells there was a negative correlation between miR138 and a DNA excision repair cross-complementation group protein (ERCC1). ERCC1 is a part of the enzyme complex ERCC1-XPF responsible for the DNA repair. Consequently, down-regulation of ERCC1 by overexpressed miR-138 influenced the CDDP-resistance in A549/CDDP cells. This agrees to the down-regulation of miR-138 in NSCLC tissue and four different NSCLC cell lines in comparison to non-malignant lung tissue [39]. Moreover, overexpression of miR-138 in NSCLC cell suppresses cell proliferation and induces apoptosis in vitro and suppresses NSCLC tumor growth in a xenograft mouse model, indicating miR-138 as a potential tumor suppressor. Interestingly, in this study the enhancer of zeste homolog 2 (EZH2) was identified as a direct target of miR-138. The EZH2, an oncogene with a histonelysine N-methyltransferase activity, has been linked to initialization and propagation of different malignancies. Upregulated miR-138 can inhibit cell mitosis and cell growth in NSCLC and increase sensitivity to CDDP by directly regulating cyclin D3 (CCND3) [40]. Further genes identified as targets of miR-138 in NSCLC tissues and cell lines are: 3-phosphoinositide-dependent protein kinase-1 (PDK1) [41], forkhead box P4 (FOXP4) [42], G-proteincoupled receptor kinase-interacting protein 1 (GIT1) and semaphoring 4C (SEMA4C) [43], yes-associated protein 1 (YAP1) [44], and LIM domain kinase (LIMK1) [45]. However, it is not known whether these target genes play any role in CDDP-resistance of NSCLC cells.

Galluzzi et al. showed that miR-181a increases sensitivity of A549 cells to CDDP by stimulating Bax oligomerization and activation of caspases, thus activating mitochondrial apoptosis. The same study showed that Mir-630 has a protective role against CDDP, due to partial inhibition of p53-regulated pro-apoptotic signaling pathways in A549 cells [13]. Recently, it has been shown that overexpressed miR-181a promotes invasion and migration of lung adenocarcinoma cells by directly targeting PTEN. It influences metastatic features, epithelial-mesenchymal transition (EMT) and promotes CDDP-resistance in lung adenocarcinoma cells [46]. These findings suggest miR-181a as an interesting target for development of new therapeutic strategies in NSCLC patients, both alone, as well as in combination with existing chemotherapies.

MiR-451 targets many different genes involved in cell proliferation, apoptosis, EMT and chemoresistance of lung adenocarcinoma. The level of miR-451 was reduced in CDDP-resistant in comparison to parental lung carcinoma cell lines. Bian et al. showed in their in vitro and in vivo experiments that upregulation of miR451 inhibits growth of NSCLC cells and increases their sensitivity to CDDP by inducing cell apoptosis [47]. Furthermore, overexpression of miR-451 sensitizes A549/
CDDP cells to CDDP by directly targeting MCL-1, an anti-apoptotic protein and member of the Bcl-2 family, and suppresses A549 cells derived xenograft tumor growth in the presence of CDDP [48]. Altogether, this suggests that miR-451 has a tumor suppressive role in NSCLC cells. Bcl-1 is also a target of miR-135a/b, which is downregulated in CDDP-resistant A549 cells [49]. In A549 cells transfected with miR-135a/b mimics, the MCL1 expression was decreased, and so was the cell resistance to CDDP. These data indicate that miR-135a/b can at least partially sensitize CDDP-resistant NSCLC cells to CDDP by repressing MCL1 and influencing apoptosis.

Several studies found dysregulation of miR-98, which also modulates CDDP-resistance. Expression of miR-98 induces apoptosis by targeting high mobility group A2 (HMGA2) oncogene, thus making cells more sensitive to CDDP [50]. Another study demonstrated that miR-98 was down-regulated in NSCLC tissue $(n=$ 8) compared to adjacent non-malignant lung tissue. Mir98 inhibits proliferation, cell migration and invasion, and induces apoptosis in human NSCLC cells. MiR-98 negatively regulates $\mathrm{P} 21$-activated protein kinase (PAK1) at the posttranslational level, and therefore inhibits cell growth and proliferation in NSCLC cells [51].

Based on elevated expression level in plasma samples of NSCLC patients, MiR-21 was suggested as a potential biomarker for diagnosis of NSCLC at an early stage, and as a predictive indicator for the sensitivity to platinum-based chemotherapy [52]. In numerous studies elevated miR-21 expression in NSCLC cell lines and tissue specimens was shown $[9,53,54]$. Elevated miR21 expression is related to increased growth, migration and invasion, whereas its down-regulation inhibits these processes in NSCLC cells. It has been found that miR21 promotes CDDP-resistance by inhibiting apoptosis via directly targeting PTEN, the expression of which is frequently downregulated in NSCLC tissues [9, 54]. As shown in Fig. 1A, PTEN is one of the most prominent target genes involved in resistance of NSCLC cells to CDDP, whose expression is regulated by many different miRNAs. In addition, it has been shown that $\mathrm{NF}-\kappa \mathrm{B}$ regulates the expression of miR-21 by binding its promoter, strongly indicating the importance of NF$\kappa \mathrm{B} / \mathrm{miR}-21 / \mathrm{PTEN}$ pathway in development of CDDPresistance in NSCLC cells [54]. Thus, down-regulation of miR-21 might provide a new potential strategy for treatment of NSCLC patients.

Resistance of non-small cell lung cancer cells to CDDP is also mediated by miR-503. The expression of miR-503 is decreased in the CDDP-resistant non-small cell lung cancer cells compared with the parental cells. The over-expression of miR-503 sensitizes the A549/ CDDP cells to CDDP, whereas the inhibition of miR503 in the A549 cells increases resistance to CDDP. MiR-503 specifically targets Bcl-2, an anti-apoptotic protein upregulated in A549/CDDP cells. The ectopic 
expression of miR-503 reduces the Bcl-2 protein level and sensitizes the A549/CDDP cells to CDDP-induced apoptosis [55]. Another study showed that miR-503 regulates the resistance of non-small cell lung cancer cells to CDDP, at least in part, by targeting FANCA (Fanconi anemia complementation group A protein). This suggests that targeting FANCA may provide a novel strategy for the sensitization of NSCLC to CDDP [56]. Lung cancer cells may express increased levels of FANCA. Overexpression of FANCA was indirectly associated with the hypermethylation and downregulation of miR503 in NSCLC. In CDDP-resistant cells the level of DNA (cytosine-5)-methyltransferase 1 (DNMT1) was increased, suggesting that enhanced expression of DNMT1 takes part in methylation of miR-503.

Mir-148b, a member of miR-148/152 family, was found to be notably down-regulated in CDDP-resistant NSCLC cells [57]. DNMT1 was detected as a direct target of miR-148b. DNMT1 mediates the transfer of methyl groups from S-adenosylmethionine to the 5 position of cytosine bases in the dinucleotide sequence $\mathrm{CpG}$ [58], thus mediating transcriptional silencing in cancer cells. MiR-148b exerts negative effects on DNMT1 expression by targeting its 3'-UTR in A549/CDDP cells. Furthermore, silencing DNMT1 increased the sensitivity of A549/ CDDP cells to CDDP and over-expression of DNMT1 reversed the pro-apoptosis effects of a miR-148b mimic [57]. DNMT1 also modulated CDDP-resistance in ovarian cancer cells by targeting miR-152 and miR-185 [59].

MiR-212 inhibits CDDP-induced apoptosis by directly targeting AChE-S in NSCLC cells [60]. $\mathrm{Lu}$ and colleagues examined different types of the acetylcholinesterase (AChE) and its alternative splicing forms like synaptic AChE (AChE-S), readthrough AChE (AChE-R) and erythrocyte AChE (AChE-E). They indicated that the AChE-S plays a role in CDDPstimulated cell apoptosis. A study from Donzelli et al. suggested that mutant $\mathrm{p} 53 \mathrm{R} 175 \mathrm{H}$ (a hotspot p53 mutant) induces miR-128-2 expression, which further up-regulates the expression of $\mathrm{p} 21^{\text {wafl }}$ by suppressing the E2F5 transcriptional repressor activity on the $\mathrm{p} 21^{\text {wafl }}$ promoter [61]. Consecutively, over-expressed $\mathrm{p} 21^{\text {wafl }}$ protein is translocated from nucleus to cytoplasm, where it binds to the pro-caspase-3, thereby executing its anti-apoptotic function. Altogether, transcriptional induction of miR128-2 results in an increased CDDP-resistance of NSCLC cells.

Another miRNA which is included in CDDPresistance development in lung cancer cells is miR-10a. Down-regulation of miR-10a induces cell apoptosis, whereas its up-regulation might inhibit apoptosis. MiR10a suppressed MDR1, MRP1 and RhoE expression, thus enhancing the CDDP efflux and cell resistance to CDDP [62]. Xie et al. showed that upregulation of miR218 activates cell apoptosis and promotes sensitivity of NSCLC to CDDP. They showed that miR-218 directly targets and negatively regulates the RUNX2 gene. In contrast, down-regulation of miR-218 induces chemoresistance to CDDP [63].

Up-regulated miR-26a induces cell apoptosis and increases cells sensitivity to CDDP by targeting HMGA2, whereas down-regulation of miR-26a shows the opposite effects. In vivo and in vitro experiments demonstrated that miR-96 targets SAMD9 in NSCLC cells. Up-regulated miR-96 suppressed cell apoptosis by down-regulating the SAMD9 [64]. Down-regulation of miR-141 increased the sensitivity to CDDP and influenced cell apoptosis by targeting PDCD4 [65].

One recent study suggested that miR-379 was down-regulated in NSCLC cell lines and tumor tissue [66]. Furthermore, miR-379 expression was lower in chemoresistant in comparison to chemosensitive tumors, as well as in more aggressive NSCLC cells (A549 and H1299) and their CDDP-resistant sublines. Manipulation of miR-379 expression level showed that miR-379 influences CDDP-induced apoptosis in NSCLC cells by directly targeting the eukaryotic initiation factor $4 \mathrm{G}$ (EIF4G), therewith acting as a tumor suppressor.

\section{MiRNAs and drug uptake in CDDP-resistant NSCLCs}

In order to overcome toxic drug effects and modify their chemoresistance, cancer cells can deregulate the expression of different transporter-molecules responsible for drug influx and efflux. One large protein family containing active transmembrane proteins responsible for modulation of cell metabolism and cellular toxicity is the family of ATP-binding cassette (ABC) transporters. In humans, this protein family contains 48 members classified into 7 distinct subfamilies, based on their sequence and gene structure homology. There is accumulating evidence that the expression level of some of these transporters is regulated by different miRNAs.

MiR-31 was detected as a factor involved in CDDP-resistance in NSCLC. Upregulation of miR-31 induces CDDP-resistance and inhibits its direct target ABCB9, an ATP-binding cassette, sub-family B member 9. Mir-31 expression is increased in CDDP-resistant NSCLC cell lines and inversely correlated with ABCB9 expression, the inhibition of which is required for CDDP resistance development [67]. Thus, miR-31 might be used as a biomarker to predict NSCLC patients' response to chemotherapy. Upregulation of miR106a in CDDPresistant A549 cells (A549/CDDP) may induce CDDPresistance by directly targeting $\mathrm{ABCA} 1$, a member 1 of the human transporter subfamily ABCA [68]. Seven different transporter genes able to regulate drug uptake ( $A B C A 1, A B C C 5, A B C C 6, A B C C 9, A B C D 2, A B C G 2$ and $A B C G$ ) have been identified by three different algorithms. ABCA1 showed the highest frequency for a putative binding site of miR-106a, which has been confirmed 
by an experimental approach. Overexpressed miR106a significantly decreased ABCA1, thereby reducing the CDDP uptake and CDDP-induced apoptosis in A549/ CDDP cells [68]. This suggested that miR-106a might be a biomarker for prediction of a clinical response to CDDP therapy. Recently, it was shown that miR-185-5p modifies CDDP-resistance by targeting ABCC1 (ATPbinding, cassette, subfamily $\mathrm{C}$ member 1 ), a relevant tumor suppressor [69].

A study from Song et al. showed that miR - 495 is downregulated in A549/CDDP cells and CDDP - resistant tissues, compared to parental A549 cells and CDDP sensitive tissues [70]. Significant down-regulation of miR-495 was also found in 56 NSCLC tissue samples in comparison to adjacent non-malignant lung tissue [71]. In other cell types this miRNA works as an oncogene [72], or as a tumor suppressor [73]. In NSCLC cell lines, miR495 suppresses the copper transporting P-type adenosine triphosphatase A (ATP7A), and thereby regulates the intracellular CDDP concentration [70]. These data are supported by previous studies showing that ATP7A is involved in CDDP-resistance in various tumor cell lines like NSCLC, ovarian cancer, oral squamous cancer and epidermoid cancer cells [74-77]. As each miRNA usually has different target genes, the MTA3 (metastasis-associated protein 3), a protein frequently over-expressed in NSCLC tissue, was also identified as a target of miR-495 [71]. Experimental data show that over-expression of miR-495 inhibits proliferation, colony forming ability and migration, and leads to cell accumulation in the G0/G1 phase. Although the connection between MTA3 and CDDP-resistance was not described, these results support the role of miR-495 in CDDP-resistance. MiRNAs involved in CDDP-resistance of NSCLC cells, which are mainly assigned to drug uptake, are summarized in Table 3.

\section{MiRNAs and cell migration, invasion, and metastasis in CDDP-resistant NSCLCs}

The development of tumor metastases is responsible for poor prognosis and for less effective treatment of cancer in general and NSCLC in particular. In the present literature, numerous correlations between different miRNAs and development of lung cancer metastases have been described. A reverse correlation between miR-200c expression and in vitro cell invasion, as well as in vivo metastasis formation has been shown [8]. In NSCLC tumor specimens $(n=69)$ decreased miR-200c expression was associated with aggressive tumor behavior, poor tumor differentiation and significantly elevated number of lymph node metastases. In addition, transfected NSCLC cells overexpressing miR-200c show an increased cytotoxicity upon CDDP treatment, which is primarily based on the finding of an elevated apoptotic rate. Based on all these data, it seems that suppressed expression of miR-200c is tightly connected with an aggressive, undifferentiated, metastatic and CDDP-resistant phenotype at least in some NSCLCs.

One important characteristic of cancer cell metastases is cell migration. MiR-26b has been shown to be downregulated in different NSCLC cells and tumor specimens [78]. Although in vitro up- or downregulation of miR-26b do not have any effect on NSCLC cell proliferation, tumor cells overexpressing miR-26b show significantly increased cell migration and CDDPresistance. It was demonstrated that PTEN acts as a direct target of miR-26b in H1299 and A549 NSCLC cell lines, and that all those effects can be reversed by PTEN overexpression [78]. Depending on the cell type, miR-217 can act either as an oncogene or as a tumor suppressor gene. MiR-217 was down-regulated in $77 \%$ of lung cancer samples $(n=100)$ compared to adjacent non-malignant tissue [79]. Overexpression of miR-217 suppresses the proliferation of lung cancer cells in vitro and tumor growth in vivo. MiR-217 also inhibits cell migration and invasion of lung cancer cells by targeting KRAS and thereby enhancing lung cancer cell sensitivity to CDDP. This strongly suggests that miR-217 works as a tumor suppressor in lung cancer.

Down-regulation of tumor suppressors or upregulation of oncogenes facilitates cancer development. Yang et al. showed that miR-98 is down-regulated in NSCLC cells and tissue and is directly targeting PAK1, a family member of serine/threonine $\mathrm{p} 21$-activating kinases, which regulate cell motility and morphology [51]. MiR98 inhibits cell proliferation, migration, invasion, and apoptosis in NSCLC cells, whereas overexpression of PTEN leads to exactly opposite effects. These data put PTEN in light as a major miRNA-regulated target responsible for CDDP-resistance of NSCLC cells. MiR206 is one of the best characterized miRNAs and its down-regulation has been described in various cancer types. Recently, in CDDP-resistant NSCLC cell lines down-regulation of miR-206 was associated with low CDDP sensitivity [80]. In vitro and in vivo overexpression of miR-206 reduced resistance, migration and invasion of CDDP-resistant cells and suppressed EMT by directly targeting the proto-oncogene MET and its downstream PI3K/AKT/mTOR pathway. Taken together, these data indicate that overexpression of miR-206 and/or inactivation of its target genes might reverse the CDDPresistance in lung adenocarcinoma cells, leading to a better response to CDDP therapy.

Some members of the miRNA-17 family (miR17, miR-20a and miR-20b) have a potential as key regulatory factors in CDDP-resistance. Down-regulation of all three members were detected in CDDP-resistant A549 cells in comparison to sensitive cells. The TGF- $\beta$ receptor 2 (TGFßR2) was detected as a direct target of these three miRNAs [81]. Overexpression of miRNA-17, $20 \mathrm{a}$ and 20b decreases both CDDP-resistance and EMT, and increases migration of CDDP-resistant A549 
Table 3: MiRNAs involved in other pathways responsible for resistance of NSCLC cells to CDDP

\begin{tabular}{|c|c|c|c|c|c|}
\hline miRNA & Targets & Cells / Tissue & $\begin{array}{l}\text { Expres- } \\
\text { sion }\end{array}$ & Function & Reference \\
\hline \multicolumn{6}{|l|}{ Migr. / Inv. / Met. } \\
\hline $\begin{array}{l}\text { miR-17 family } \\
(20 \mathrm{a}, 20 \mathrm{~b})\end{array}$ & TGFßR2 & A549/CDDP & down & $\begin{array}{c}\text { TGFßR2 suppressor, reverses CDDP-resistance and sup- } \\
\text { presses metastases }\end{array}$ & {$[81]$} \\
\hline miR-21 & PTEN & Serum, NSCLC cells & up & Promotes migration, invasion and metastasis & [9] \\
\hline mir-26b & PTEN & $\begin{array}{l}\text { NSCLC tissue, } \\
\text { NSCLC cells }\end{array}$ & down & Regulates NSCLC migration and CDDP-chemosensitivity & {$[78]$} \\
\hline $\operatorname{miR}-27 \mathrm{a}$ & RKIP & A549/CDDP & up & Regulates EM-transition and CDDP-resistance & {$[82]$} \\
\hline miR-98 & PAK1 & $\begin{array}{l}\text { NSCLC tissue, A549/ } \\
\text { PAR }\end{array}$ & down & Inversely regulates PAK1, inhibits migration and invasion & {$[51]$} \\
\hline miR-182 & PDCD4 & A549 cells & up & Induces resistance to CDDP by targeting PDCD 4 & {$[84]$} \\
\hline $\operatorname{miR}-200 \mathrm{c}$ & n. d. & $\begin{array}{l}\text { NSCLC cell lines } \\
\qquad(\mathrm{n}=9)\end{array}$ & down & $\begin{array}{l}\text { Inversely correlates with aggressive, invasive and chemore- } \\
\text { sistant phenotype }\end{array}$ & {$[8]$} \\
\hline miR-206 & MET & $\begin{array}{l}\text { NSCLC tissue, A549/ } \\
\text { CDDP, H1299/CDDP }\end{array}$ & down & $\begin{array}{l}\text { Inhibits CDDP-resistance via MET dependent PI3K/AKT/ } \\
\text { mTOR pathways }\end{array}$ & {$[80]$} \\
\hline miR-217 & KRAS & $\begin{array}{l}\text { NSCLC tissue, A549/ } \\
\text { PAR }\end{array}$ & down & $\begin{array}{l}\text { Inhibits proliferation, migration and invasion, promotes } \\
\text { apoptosis and sensitivity to CDDP }\end{array}$ & [79] \\
\hline \multicolumn{6}{|l|}{$\begin{array}{l}\text { DNA damage } \\
\text { response }\end{array}$} \\
\hline $\begin{array}{l}\mathrm{miR}-17 / \mathrm{miR}-92 \\
\text { families }\end{array}$ & $\begin{array}{l}\text { TGFßR2, } \\
\text { CDKN1A, } \\
\text { RAD21 }\end{array}$ & A549/CDDP & down & $\begin{array}{l}\text { Influence CDDP-resistance by synergistic and combined } \\
\text { regulation of their target genes }\end{array}$ & {$[127]$} \\
\hline $\operatorname{miR}-33 b-3 p$ & P21WAF1 & A549/CDDP & up & Impairs the DNA damage response & {$[128]$} \\
\hline \multicolumn{6}{|l|}{ miR-92 } \\
\hline $\operatorname{miR}-138$ & ERCC1 & A549/CDDP & up & Negatively regulates ERCC1 expression & {$[38]$} \\
\hline $\operatorname{miR}-155$ & APAF-1 & $\begin{array}{l}\text { NSCLC tissue, A549/ } \\
\text { PAR }\end{array}$ & up & $\begin{array}{l}\text { Inhibits sensitivity to CDDP via negative regulation of } \\
\text { Apaf-1 }\end{array}$ & {$[37]$} \\
\hline miR-509-3-5p & PLK1 & $\begin{array}{l}\text { CDDP-treated A549/ } \\
\text { PAR }\end{array}$ & down & $\begin{array}{c}\text { Tumor suppressor, causes aberrant mitosis and anti-prolifer- } \\
\text { ative effects by suppressing PLK1 }\end{array}$ & {$[20]$} \\
\hline miR-630 & $\begin{array}{l}\text { ATM, H2AX, } \\
\text { p53 }\end{array}$ & $\begin{array}{l}\text { A549/PAR CDDP- } \\
\text { treated }\end{array}$ & up & Blocks DNA-damage response & {$[13]$} \\
\hline \multicolumn{6}{|l|}{ Drug uptake } \\
\hline $\operatorname{miR}-15 b$ & PEBP4 & $\begin{array}{l}\text { A549/CDDP, NSCLC } \\
\text { tissue }\end{array}$ & up & $\begin{array}{l}\text { Suppresses PEBP4 expression and contribute to CDDP- } \\
\text { resistance }\end{array}$ & [129] \\
\hline miR-31-p & Dicer & A549 cells & n. d. & Enhances sensitivity to CDDP by repressing Dicer & [130] \\
\hline miR-34a & $\begin{array}{l}\text { PEBP4, } \\
\text { MYCN }\end{array}$ & A549/PAR & up & $\begin{array}{c}\text { Modulates CDDP-sensitivity in NSCLC cells by regulating } \\
\text { PEBP4 expression }\end{array}$ & [131] \\
\hline miR-106a & ABCA1 & A549/CDDP & up & $\begin{array}{l}\text { Induces CDDP-resistance by targeting ABCA1 and inhibit- } \\
\text { ing apoptosis }\end{array}$ & {$[68]$} \\
\hline $\operatorname{miR}-148 b$ & DNMT1 & $\begin{array}{l}\text { A549/CDDP, SPC-A1/ } \\
\text { CDDP }\end{array}$ & down & Influence CDDP-sensitivity, cell viability and apoptosis & {$[57]$} \\
\hline $\operatorname{miR}-181 \mathrm{a}$ & PTEN & A549/CDDP & up & $\begin{array}{c}\text { Regulates epithelial-mesenchymal transition and metastatic } \\
\text { properties of NSCLC cells }\end{array}$ & {$[46]$} \\
\hline $\operatorname{miR}-185-5 p$ & $\mathrm{ABCC} 1$ & A549/CDDP & down & Promotes CDDP-induced apoptosis by suppressing ABCC1 & {$[69]$} \\
\hline $\operatorname{miR}-495$ & ATP7A & $\begin{array}{l}\text { NSCLC tissue, A549/ } \\
\text { CDDP }\end{array}$ & down & $\begin{array}{l}\text { Negatively regulates ATP7A and modulates CDDP-induced } \\
\text { apoptosis }\end{array}$ & {$[70]$} \\
\hline miR-503 & FANCA & $\begin{array}{l}\text { NSCLC tissue, A549/ } \\
\text { CDDP }\end{array}$ & down & Regulates CDDP-resistance by targeting FANCA & {$[102]$} \\
\hline
\end{tabular}

n. d., not defined; Expression = expression in CDDP-resistant cells or NSCLC tissue in comparison to sensitive cells or non-malignant lung tissue. 
cells. Altogether, this indicates that miRNA-17 family members at least partially influence CDDP-resistance and participate in metastatic mechanisms of NSCLC cells. Further studies would be necessary to define whether miR-17 family members are useful as predictive biomarkers for sensitivity to CDDP-based chemotherapy in NSCLC.

In comparison to parental cells, CDDP-resistant A549 cells show a prominent up-regulation of miR27a [82]. In vitro inhibition of miR-27a suppressed the invasion of CDDP-resistant cells and enhanced their sensitivity to CDDP. In vivo experiments in nude mice, injected with A549 cells stably expressing miR-27a and treated with CDDP, show dramatic increase of lung metastasis in the miR-27a over-expressing group, with exactly opposite results in animals injected with miR27a antagomir-transduced cells. These data indicate that miR-27a induces mesenchymal features, promotes tumor metastasis, and CDDP-resistance in NSCLC cells, by directly targeting RKIP (Raf Kinase Inhibitory Protein) [82].

Overexpression of miR-182 was found in different human cancers, including NSCLC. Mir-182 overexpression was also shown in CDDP-resistant A549 in comparison to parental cells [83]. Suppressing miR-182 expression by a specific inhibitor enhanced sensitivity of A549 cells to CDDP by negatively regulating the tumor suppressor PDCD4 (Programed Cell Death 4 Protein) [84]. As already mentioned in the context of apoptosis regulation and drug uptake, miR181 directly targets PTEN [46]. Thereby miRNA-181 not only influences apoptosis, but also promotes invasion and migration of NSCLC cells. MiRNAs involved in CDDPresistance of NSCLC cells, which are mainly assigned to migration, invasion and metastasis, are summarized in Table 3.

Based on the present literature, one can easily conclude that miRNAs are frequently multiplayers involved in the regulation of various target genes and cellular processes. In fact, it seems that the vast majority of miRNAs have this characteristic, which makes every classification, prediction, and understanding of possible cross-reactions very challenging.

\section{MiRNAs and hypoxia in NSCLCs}

Hypoxia is a common microenvironmental feature and a distinctive property of solid tumors, resulting from shortness of supply with oxygen. Different cellular responses to hypoxia are frequently mediated by changes in targeted gene expression. One of the most important and well described factors deregulated under hypoxic conditions is the hypoxia-inducible factor-1 (HIF-1). Members of the HIF-family (HIF- $1 \alpha$, HIF- $1 \beta$ and HIF- $2 \alpha$ ) bind to hypoxia-response elements (HRE) in the promoter regions of target genes, thereby acting as transcription factors and regulators of gene expression. The present literature data differ very much concerning the number of target genes, speculating that 150 to 500 genes might be regulated by HIF proteins. These target genes are involved in different cellular processes such as cell metabolism, apoptosis, proliferation and cell cycle, autophagy, angiogenesis, etc. HIF-1 consists of two subunits: hypoxia-inducible HIF- $1 \alpha$ and non-oxygen-responsive, constitutively expressed HIF-1ß. HIF- $1 \alpha$ is overexpressed and its overexpression is associated with increased patient mortality in different human cancers. Overexpression of HIF-1 $\alpha$, both at the RNA and at the protein level, was also shown in NSCLC patients and was associated with a poor prognosis. Expression of HIF proteins in lung carcinoma can also be regulated by different miRNAs. Many miRNAs have been found to be involved in the regulation of the cellular response to hypoxia, both in tumor and in non-malignant cells (for summary see Table 4).

One of the first, and in the meantime probably the best described miRNAs, identified in the subset of hypoxia-regulated miRNAs, is miR-210. MiR-210 has been described as a "micro-manager of the hypoxia pathway" [85] and its overexpression has been shown in numerous tumors including NSCLC [86-90]. It was shown that miR-210 expression is progressively increased with growth and invasion of tumor cells, being the highest in late-stage NSCLCs [91]. Furthermore, miR-210 expression is also correlated with a hypoxic signature in NSCLCs and is increased in A549 cells under hypoxic conditions. MiR-210 expression alters cell viability and enhances caspase-3/7 activity in A549 lung adenocarcinoma cells and increases HIF-1 $\alpha$ activity. The authors suggest miR-210 to directly target the SDHD (subunit D of succinate dehydrogenase complex), thus revealing a positive auto-regulatory loop associating miR-210 and HIF-1 $\alpha$. In their subsequent study, Grosso et al. developed a NSCLC-derived cell line (A549) stably expressing miR-210, and showed a significant stabilization of HIF-1 $\alpha$ in those cells and increased radioresistance under hypoxic conditions [92]. This is, at least partially, based on more efficient double-strand break (DSB) repair in miR-210 overexpressing cells, as shown with immunofluorescence of $\mathrm{p} 53$-binding protein (53BP1) and $\gamma \mathrm{H} 2 \mathrm{AX}$, two markers of DSB-induced DNA repair. These findings might be highly relevant, because it is well known that hypoxic cells are more resistant to radio- and chemotherapy than normoxic cells. Although the molecular mechanism is not fully understood, it seems that miR-210 influences mitochondrial function, since overexpressing cells show enlarged mitochondria with rearranged cristae. In addition, miR-210 overexpressing cells show an increased glycolytic rate in comparison to control cells with low miR-210 expression. Based on those results, miR-210 seems to be a possible prognostic and predictive biomarker for NSCLC. This prognostic 
Table 4: Hypoxia-deregulated miRNAs in NSCLCs

\begin{tabular}{|c|c|c|c|c|c|}
\hline miRNA & Target genes & $\begin{array}{l}\text { Correlation } \\
\text { with HIF- } \\
\quad 1 \alpha\end{array}$ & $\begin{array}{l}\text { Entity (regulation } \\
\text { under HOX) }\end{array}$ & Main function of miRNA & Reference \\
\hline miR-15a & n. d. & neg. & NSCLC (down) & $\begin{array}{l}\text { n. d., miR-15a expression negatively correlates with } \\
\text { HIF- } 1 \alpha\end{array}$ & [132] \\
\hline $\begin{array}{l}\operatorname{miR} 17- \\
92 \mathrm{cl} .\end{array}$ & HIF- $1 \alpha$ & neg. & Lung cancer (up) & $\begin{array}{l}\text { Mediate HIF-1 } \alpha \text { inhibition of cell growth in normoxic } \\
\text { conditions }\end{array}$ & [133] \\
\hline $\operatorname{miR}-21$ & HIF- $1 \alpha$ & pos. & $\begin{array}{l}\text { Adenocarcinoma and } \\
\text { radioresistant NSCLC } \\
\text { (up) }\end{array}$ & $\begin{array}{l}\text { Influences cancer cell adaptation to tumor-specific } \\
\text { environment, promotes glycolysis and modulates } \\
\text { radioresistance by upregulation of HIF-1 } \alpha\end{array}$ & [134-136] \\
\hline miR-23a & PHD1, PHD2, ZO-1 & pos. & Adenocarcinoma (up) & Enhances neovascularization and tumor growth & [137] \\
\hline miR-101 & $\begin{array}{l}\text { Cox2, Lin28B, let-7 } \\
\text { miRNA }\end{array}$ & neg. & NSCLC (down) & Tumor suppressive function in NSCLC & [138] \\
\hline miR-143 & IGF-IR, IRS1 & neg. & $\begin{array}{l}\mathrm{Cr}(\mathrm{VI}) \text {-transformed } \\
\text { lung epithelial cells } \\
\text { (down) }\end{array}$ & Antiangiogenic effects & [139] \\
\hline miR-155 & FOXO3A, TP53INP1 & pos. & NSCLC (up) & Shows radio-protective effect in NSCLC cell lines & {$[140]$} \\
\hline miR-191 & NF1A & pos. & NSCLC (up) & Promotes cell proliferation and migration under HOX & [141] \\
\hline miR-199a & HIF- $1 \alpha$ & neg. & NSCLC (down) & $\begin{array}{l}\text { Suppresses hypoxia-induced proliferation of NSCLC } \\
\text { cell }\end{array}$ & [96] \\
\hline $\operatorname{miR}-210$ & $\begin{array}{l}\text { NDUFA4, SDHD, PTPN1, } \\
\text { TP53I11, HOXA1, } \\
\text { HIF-1 } \alpha\end{array}$ & pos. & $\begin{array}{l}\text { NSCLC, NSCLC - late } \\
\text { stage (up) }\end{array}$ & $\begin{array}{c}\text { Influences cell viability, activates caspase } 3 / 7, \\
\text { promotes double-strand break repair, and increases } \\
\text { radioresistance in NSCLC cells. }\end{array}$ & $\begin{array}{c}{[92,142,} \\
143]\end{array}$ \\
\hline $\begin{array}{l}\mathrm{miR}- \\
301 \mathrm{~b}\end{array}$ & Bim & pos. & $\begin{array}{l}\text { NSCLC specimens and } \\
\text { cell lines (up) }\end{array}$ & $\begin{array}{c}\text { Enhances cell proliferation, reduces apoptosis, } \\
\text { increases resistance to chemotherapy }\end{array}$ & [144] \\
\hline miR-494 & PTEN & pos. & NSCLC cells (up) & $\begin{array}{l}\text { Enhances endothelial cell migration, promotes } \\
\text { angiogenesis and tumor growth under HOX }\end{array}$ & [97] \\
\hline $\operatorname{miR}-519 c$ & HIF- $1 \alpha$ & neg. & NSCLC cells (n. d.) & $\begin{array}{l}\text { Suppresses tumor angiogenesis, growth, and } \\
\text { metastasis }\end{array}$ & [145] \\
\hline miR-622 & HIF- $1 \alpha$ & neg. & NSCLC cells (down) & Inhibits cancer cell migration and invasion & [99] \\
\hline $\begin{array}{l}\mathrm{miR}- \\
1908\end{array}$ & AKT1S1 & n. d. & NSCLC (down) & Suppresses cell proliferation & [146] \\
\hline
\end{tabular}

HOX, hypoxia; neg., negative; pos., positive; cl., cluster; n. d., non-determined; NSCLC, non-small cell lung carcinoma; CTL, cytotoxic T lymphocytes.

impact was further supported by a large-scale study from Eilertsen et al. showing miR-210 expression on tissue micro array data of 335 patients with stage I-IIIA NSCLC [93]. They showed that high expression of miR-210 in both cancer and stromal cells of the tumor is associated with improved survival. Concerning correlation between miR-210 and different hypoxia markers in this patient cohort, there was no correlation with carbo anhydrase IX (CAIX), but there was a significant positive correlation with both HIF1 and HIF2. The authors concluded that miR-210 might serve as a prognostic biomarker in NSCLC patients and its reintroduction may be an interesting future treatment approach. Interestingly, in their cohort with 80 NSCLC patients, Osugi et al. showed correlation of miR-210 expression with lymph node metastasis, late disease stage and poor prognosis in patients with lung adenocarcinoma [94]. Although data from those two studies are contradictory, they both suggest that miR-210 could be used as a prognostic marker in NSCLC patients.

MiR-199a suppresses the hypoxia-induced proliferation of NSCLC by targeting HIF-1 $\alpha$ [95]. Ding et al. showed that miR-199a expression is negatively correlated with HIF-1 $\alpha$ expression in NSCLC patients. The expression of miR-199a was significantly lower in lung tumors as compared to adjacent non-malignant tissue and was strongly negatively correlated with tumor progression. Results based on the overexpression of miR199a in low miR-199a-expressing NSCLC cells, and on inhibition with a specific HIF-1 $\alpha$ inhibitor PX-478 suggest that miR-199a has an inhibitory effect on the hypoxiainduced proliferation of NSCLC cells, through negative regulation of HIF-1 $\alpha$ and blocking of HIF-1 $\alpha$-mediated glycolysis [96]. Altogether, these data suggested opposite roles of miR-199a and HIF-1 $\alpha$ in NSCLC progression.

Hypoxia is well known as a primary factor stimulating angiogenesis. It has been shown that miR494 expression in A549 cells is induced in response to hypoxia, thereby promoting cell migration, angiogenesis and tumor growth under hypoxic conditions [97]. MiR-494 is a tumor-derived pro-angiogenic stimulus upregulated via HIF-1 $\alpha$-mediated transcriptional activation. It also inhibits tumor angiogenesis in vivo, and therefore might be a promising anti-angiogenic strategy for cancer therapy. Furthermore, miR-494 expression in NSCLC 
tissue is higher than in non-malignant lung tissue, and was positively correlated with pathological staging of NSCLC patients. The negative correlation of increased miR-494 with the survival indicates that miR-494 is an independent prognostic factor for NSCLCs. Interestingly, in gastric cancer, miR-494 was also described as a tumor suppressor targeting c-myc [98].

Another interesting and promising miRNA responsible for metastatic spread of lung cancer cells is miR-622. Cheng and coworkers showed in A549 lung cancer cells that miR-622 directly binds to the 3 '-untranslated region of HIF- $1 \alpha$ mRNA and decreases its expression [99]. Overexpression of miR-622 efficiently reduces the HIF-1 $\alpha$ level, thereby diminishing the migration and invasion abilities of cancer cells. Mir-622 influences and suppresses metastasis in xenograft model of lung cancer via inhibition of HIF- $1 \alpha$-related EMT signaling. Furthermore, miR-622 expression is regulated by the transcription factor FOXO3a. Altogether, the authors suggest that miR-622 could be a promising target for the development of miRNA-based therapeutics for metastatic lung cancer. Unfortunately, there comes another complexity into play. Not only HIF-1 $\alpha$ expression is controlled by different miRNAs, but HIF-1 $\alpha$ itself controls the expression of various miRNAs. However, a detailed description of those cross-links would be out of the scope of this review.

\section{Prognostic impact of circulating microRNAs in CDDP-resistant NSCLCs}

Prognosis for NSCLC patients is associated with TNM stage and with the development of chemoresistance. Another relevant prognostic aspect for cancer patients is metastasis formation. Unfortunately, most NSCLC patients are diagnosed at advanced stages and often metastasis is already present. MiRNAs could serve as prognostic indicators in lung cancer, as shown above. It has been observed that miRNAs are closely related to tumor development and stably exist in serum/plasma. MiRNAs are resistant to RNaseA digestion and other harsh conditions, partially explaining their stability in serum.

The relationship between miR-210 expression and disease-free and overall survival of NSCLC patients was analyzed by Osugi et al. Although no significant association between MiR-210 expression and different clinical characteristics (sex, age, tumor size, lymph node status, TNM stage) was observed, miR-210 expression was significantly correlated with disease relapse. Upregulated miR-210 was associated with poor prognosis, shorter disease-free, and overall survival of patients with lung adenocarcinoma [94]. Based on correlation between miR-210 level and patient survival, it was concluded that miR-210 acts as an independent prognostic factor in lung adenocarcinoma patients. Furthermore, a significant correlation between miR-210 level in serum and disease stage in NSCLC patients was observed. The serum level of miR-210 in the control group was significantly lower than in NSCLC patients. The expression of miR-210 in NSCLC patients was significantly correlated with higher clinical stage and with the presence of lymph node metastasis. MiR-210 level was also higher in patients with stable disease in comparison to patients with partial response to CDDP therapy [100]. This suggests that miR-210 is a good candidate as a diagnostic and prognostic biomarker in NSCLC.

MiR-216a was down-regulated in NSCLC specimens in comparison to non-malignant lung tissue [12]. Decreased expression was inversely correlated with cancer stage, metastasis, and poor survival of NSCLC patients. Down-regulation of miR-216a was associated with increased NSCLC cell growth and metastasis. Furthermore, decreased miR-216a suppressed CDDPinduced apoptosis and cell growth inhibition in NSCLC cells, thus increasing the resistance to CDDP. Therefore, in NSCLCs miR-216a may have a role as cancer suppressor and might act as biomarker for predicting NSCLC progression.

As already mentioned in this paper, miR-503 modifies NSCLC cell resistance to CDDP by influencing expression of different target genes like Bcl-2, FANCA, PI3K p85, and IKK- $\beta[55,56,101]$. Compared to nonmalignant lung tissue, in NSCLC tissues, significant down-regulation of miR-503 has been detected and miR503 levels were associated with advanced tumor stage and poor prognosis [102]. Kaplan-Meier analyses showed a worse survival of patients with lower miR-503 expression as compared to NSCLC patients with a higher expression. Based on this data and further multivariate analysis, the authors suggested that miR-503 might be an independent prognostic biomarker for overall survival in NSCLC patients.

MiR-638 was also an independent prognostic factor in NSCLC patients [11]. Interestingly, miR-638 expression in NSCLC cells is induced by CDDP-treatment both in vitro and in vivo. Despite all those promising results, it must be stressed that the exact molecular mechanisms of miR-638 in lung cancer tumorigenesis are not well known.

Circulating miR-125b was analyzed in advanced inoperable NSCLC patients who received CDDPtherapy [103]. High levels of circulating miR-125b were significantly positively correlated with cancer stage and with tumor differentiation status and poor prognosis after adjuvant chemotherapy in NSCLC patients. Thus, miR-125b might represent a biomarker for chemotherapeutic response and prognosis for NSCLC patients.

MiR-21 expression studies in plasma of NSCLC patients, in comparison to age- and sex-matched healthy controls, show significantly increased miR-21 levels [52]. Furthermore, the miR-21 level is correlated with 
TNM stage and with response to CDDP chemotherapy. Correspondingly, the authors suggest to use miR-21 as a biomarker for early diagnosis and as a predictive marker for response to platinum-based chemotherapy.

The expression of miR-107 in patients at different TNM stages was analyzed by Zhong et al. [104]. The level of miR-107 in patients with TNM stage II and IIIa was lower in comparison to patients with TNM stage I. The expression level of miR-107 was also decreased in NSCLC tissue samples compared to adjacent nonmalignant lung tissue. Mechanistically, it was shown that miR-107 directly targets cyclin dependent kinase 8 (CDK8), thus making NSCLC cells more sensitive to CDDP-therapy [21]. Thus, a low level of miR-107 is correlated with increased lung cancer progression and limited survival in NSCLC patients, suggesting that miR-107 might be used as a prognostic biomarker and to predict the response to CDDP-therapy in NSCLC patients.

Gallardo et al. showed that decreased levels of miR-34a in NSCLC patients who underwent curative surgery were correlated with an increased rate of relapse. In patients with reduced miR-34a expression, frequent mutations of the tumor suppressor p53 were observed. Patients with both decreased miR-34a levels and p53 mutations had a particularly poor prognosis, indicating that presence of these two factors leads to shortened survival of NSCLC patients after curative surgery [105]. Therefore, also miR-34a was suggested as a prognostic marker in NSCLC patients.

\section{CONCLUSIONS}

NSCLC has a very high mortality rate as compared to other cancers, and NSCLC patients are more likely to survive if they are diagnosed early and received curative therapy. Good biomarkers, predicting the response to CDDP, might help clinicians to make timely therapy decisions and maybe even to improve survival. Over the past few years, at lot of evidence has accumulated to suggest aberrant expression of miRNAs in cancer patients as compared to healthy controls. MiRNA expression may be strongly correlated with cancer development, survival, and CDDP resistance. MiRNAs are released from primary tumor cells into the peripheral circulation, where they circulate in a stable level, due to resistance to RNase digestion and other elimination factors. The high stability of serum miRNAs makes them especially interesting and promising as potential noninvasive biomarkers for NSCLC detection and as prognosticators. In addition, miRNAs and miRNA-inhibitors have a potential to be an adjunct to lung cancer treatment. In conclusion, better understanding of the molecular mechanisms behind particular miRNAs and of their role in tumor initiation, growth and development of metastases might improve diagnosis and prognosis of NSCLC patients.

\section{Abbreviations}

NSCLC, non-small cell lung carcinoma; ADC, adenocarcinoma; SCC, squamous-cell carcinoma; LCC, large-cell carcinoma; CDDP, cis-diaminedichloroplatinum (cisplatin); UTR, untranslated region; miRNA, micro RNA; EMT, epithelial-to-mesenchymal transition; GSH, glutathione; GSTP1, glutathione s-transferase P1; eIF4B, eukaryotic initiation factor 4B; ZEB1, zinc finger and homeobox transcription factor-1; PTEN, phosphatase and tensin homolog; SMAD7, SMAD family member 7; p27Kip1 (CDKN1B), Cyclin-dependent kinase inhibitor 1B; CDK, cyclin-dependent protein kinase; PLK1, pololike kinase 1; CDC, cell division cycle related protein kinase; DDIT4, DNA damage inducible transcript 4; PARP3, poly(ADP-ribose) polymerase family member 3; EP300, E1A binding protein P300; Bcl-2, apoptosis regulator Bcl-2; VEGF-A, vascular endothelial growth factor A; YAP1, yes-associated protein 1; CCNE1, cyclin E1; HDGF, hepatoma-derived growth factor; BclXL, B-cell lymphoma - extra large; Apaf-1, apoptotic peptidase activating factor 1; ERCC1, DNA excision repair cross-complementation group protein 1; EZH2, enhancer of zeste homolog 2; CCND3, cyclin D3; PDK1, 3-phosphoinositide-dependent protein kinase 1; FOXP4, forkhead box P4; GIT1, G-protein-coupled receptor kinase-interacting protein 1; SEMA4C, semaphoring 4C; LIMK1, LIM domain kinase; BAX, Bcl-2 associated X; EMT, epithelial-mesenchymal transition; HMGA2, high mobility group A2; PAK1, p21-activated protein kinase; NF-кB, nuclear factor kappa B subunit 1; FANCA, Fanconi anemia complementation group A protein; DNMT1, DNA (cytosine-5)-methyltransferase 1; AChE, acetylcholinesterase; MDR (ABCB1), ATP binding cassette subfamily B member 1; MRP1 (ABCC1), ATP binding cassette subfamily $\mathrm{C}$ member 1 ; RUNX2, runt related transcription factor 2; SAMD9, sterile alpha motif domain containing 9; PDCD4, programmed cell death 4; ATP7A, ATPase copper transporting alpha; MTA3, metastasis-associated protein 3; mTOR, mechanistic target of rapamycin; TGFßR2, transforming growth factor beta receptor 2; RKIP, raf kinase inhibitory protein; Hif-1, hypoxia-inducible factor; 53BP1, p53-binding protein 1; CAIX, carbonic anhydrase 9; FOXO, forkhead box.

\section{Author contributions}

IF drafted the manuscript, $\mathrm{HO}$ participated in the design of the study, $\mathrm{AH}$ conceptualized and wrote the manuscript. All authors read and approved the final manuscript.

\section{ACKNOWLEDGMENTS}

Not applicable. 


\section{CONFLICTS OF INTEREST} interests.

The authors declare that they have no competing

\section{FUNDING}

This study was supported by the Austrian National Bank (ÖNB) Fund \#17246 to AH, and by MEFO Graz Vereinigung Forschungsförderung Med Uni Graz to AH.

\section{REFERENCES}

1. Parkin DM, Bray F, Ferlay J, Pisani P. Global cancer statistics. 2002; CA Cancer J Clin. 2005; 55:74-108.

2. Travis WD. The 2015 WHO classification of lung tumors. Der Pathologe. 2014; 35:188.

3. Ettinger DS, Wood DE, Aisner DL, Akerley W, Bauman J, Chirieac LR, D'Amico TA, DeCamp MM, Dilling TJ, Dobelbower M, Doebele RC, Govindan R, Gubens MA, et al. Non-Small Cell Lung Cancer, Version 5.2017, NCCN Clinical Practice Guidelines in Oncology. J Natl Compr Canc Netw. 2017; 15:504-535.

4. Travis WD, Brambilla E, Noguchi M, Nicholson AG, Geisinger KR, Yatabe Y, Beer DG, Powell CA, Riely GJ, Van Schil PE, Garg K, Austin JH, Asamura H, et al. International association for the study of lung cancer/ american thoracic society/european respiratory society international multidisciplinary classification of lung adenocarcinoma. J Thorac Oncol. 2011; 6:244-285.

5. Travis WD, Brambilla E, Noguchi M, Nicholson AG, Geisinger K, Yatabe Y, Ishikawa Y, Wistuba I, Flieder DB, Franklin W, Gazdar A, Hasleton PS, Henderson DW, et al. Diagnosis of lung adenocarcinoma in resected specimens: implications of the 2011 International Association for the Study of Lung Cancer/American Thoracic Society/ European Respiratory Society classification. Arch Pathol Lab Med. 2013; 137:685-705.

6. Matsuda T, Machii R. Morphological distribution of lung cancer from Cancer Incidence in Five Continents Vol. X. Jpn J Clin Oncol. 2015; 45:404.

7. Chen CZ. MicroRNAs as oncogenes and tumor suppressors. N Engl J Med. 2005; 353:1768-1771.

8. Ceppi P, Mudduluru G, Kumarswamy R, Rapa I, Scagliotti GV, Papotti M, Allgayer H. Loss of miR-200c expression induces an aggressive, invasive, and chemoresistant phenotype in non-small cell lung cancer. Mol Cancer Res. 2010; 8:1207-1216.

9. Liu ZL, Wang H, Liu J, Wang ZX. MicroRNA-21 (miR21) expression promotes growth, metastasis, and chemoor radioresistance in non-small cell lung cancer cells by targeting PTEN. Mol Cell Biochem. 2013; 372:35-45.

10. MacDonagh L, Gray SG, Finn SP, Cuffe S, O’Byrne KJ, Barr MP. The emerging role of microRNAs in resistance to lung cancer treatments. Cancer Treat Rev. 2015; 41:160-169.

11. Wang F, Lou JF, Cao Y, Shi XH, Wang P, Xu J, Xie EF, Xu T, Sun RH, Rao JY, Huang PW, Pan SY, Wang H. miR-638 is a new biomarker for outcome prediction of non-small cell lung cancer patients receiving chemotherapy. Exp Mol Med. 2015; 47:e162.

12. Wang RT, Xu M, Xu CX, Song ZG, Jin H. Decreased expression of miR216a contributes to non-small-cell lung cancer progression. Clin Cancer Res. 2014; 20:4705-4716.

13. Galluzzi L, Morselli E, Vitale I, Kepp O, Senovilla L, Criollo A, Servant N, Paccard C, Hupe P, Robert T, Ripoche H, Lazar V, Harel-Bellan A, et al. miR-181a and miR-630 regulate cisplatin-induced cancer cell death. Cancer Res. 2010; 70:1793-1803.

14. Rathod SS, Rani SB, Khan M, Muzumdar D, Shiras A. Tumor suppressive miRNA-34a suppresses cell proliferation and tumor growth of glioma stem cells by targeting Akt and Wnt signaling pathways. FEBS Open Bio. 2014; 4:485-495.

15. Sun F, Wan M, Xu X, Gao B, Zhou Y, Sun J, Cheng L, Klein OD, Zhou X, Zheng L. Crosstalk between miR-34a and Notch Signaling Promotes Differentiation in Apical Papilla Stem Cells (SCAPs). J Dent Res. 2014; 93:589-595.

16. Li Y, Li L, Guan Y, Liu X, Meng Q, Guo Q. MiR-92b regulates the cell growth, cisplatin chemosensitivity of A549 non small cell lung cancer cell line and target PTEN. Biochem Biophys Res Commun. 2013; 440:604-610.

17. Lei L, Huang Y, Gong W. Inhibition of miR-92b suppresses nonsmall cell lung cancer cells growth and motility by targeting RECK. Mol Cell Biochem. 2014; 387:171-176.

18. Spankuch-Schmitt B, Wolf G, Solbach C, Loibl S, Knecht R, Stegmuller M, von Minckwitz G, Kaufmann M, Strebhardt K. Downregulation of human polo-like kinase activity by antisense oligonucleotides induces growth inhibition in cancer cells. Oncogene. 2002; 21:3162-3171.

19. Kneisel L, Strebhardt K, Bernd A, Wolter M, Binder A, Kaufmann R. Expression of polo-like kinase (PLK1) in thin melanomas: a novel marker of metastatic disease. J Cutan Pathol. 2002; 29:354-358.

20. Wang XH, Lu Y, Liang JJ, Cao JX, Jin YQ, An GS, Ni JH, Jia HT, Li SY. MiR-509-3-5p causes aberrant mitosis and anti-proliferative effect by suppression of PLK1 in human lung cancer A549 cells. Biochem Biophys Res Commun. 2016; 478:676-682.

21. Zhang Z, Zhang L, Yin ZY, Fan XL, Hu B, Wang LQ, Zhang D. miR-107 regulates cisplatin chemosensitivity of A549 non small cell lung cancer cell line by targeting cyclin dependent kinase 8. Int J Clin Exp Pathol. 2014; 7:7236-7241.

22. Bar J, Gorn-Hondermann I, Moretto P, Perkins TJ, Niknejad N, Stewart DJ, Goss GD, Dimitroulakos J. miR Profiling Identifies Cyclin-Dependent Kinase 6 Downregulation as a Potential Mechanism of Acquired Cisplatin Resistance in Non-SmallCell Lung Carcinoma. Clin Lung Cancer. 2015; 16:e121-129. 
23. Cao JX, Lu Y, Qi JJ, An GS, Mao ZB, Jia HT, Li SY, Ni JH. MiR-630 inhibits proliferation by targeting CDC7 kinase, but maintains the apoptotic balance by targeting multiple modulators in human lung cancer A549 cells. Cell Death Dis. 2014; 5:e1426.

24. Yang T, Chen T, Li Y, Gao L, Zhang S, Wang T, Chen M. Downregulation of miR-25 modulates non-small cell lung cancer cells by targeting CDC42. Tumour Biol. 2015; 36:1903-1911.

25. Bartel DP. MicroRNAs: genomics, biogenesis, mechanism, and function. Cell. 2004; 116:281-297.

26. Plesca D, Mazumder S, Almasan A. DNA damage response and apoptosis. Methods Enzymol. 2008; 446:107-122.

27. Ying C, Yanping G, Kai Z, Chen L, Yan P, Jing C, Rui W, Longbang C. MicroRNAs as regulators of cisplatin resistance in lung cancer. Cell Physiol Biochem. 2015; 37:1869-1880.

28. Zhang F, Li Y, Wu H, Qi K, You J, Li X, Zu L, Pan Z, Wang Y, Li Y, Li Y, Wang M, Shen W, Zhou Q. MiR-192 confers cisplatin resistance by targeting Bim in lung cancer. Chin J Lung Cancer. 2014; 17:384-390.

29. Cao J, He Y, Liu HQ, Wang SB, Zhao BC, Cheng YS. MicroRNA 192 regulates chemo-resistance of lung adenocarcinoma for gemcitabine and cisplatin combined therapy by targeting Bcl-2. Int J Clin Exp Med. 2015; 8:12397-12403.

30. Tung MC, Lin PL, Cheng YW, Wu DW, Yeh SD, Chen CY, Lee H. Reduction of microRNA-184 by E6 oncoprotein confers cisplatin resistance in lung cancer via increasing Bcl-2. Oncotarget. 2016; 7:32362-32374. https://doi. org/10.18632/oncotarget.8708.

31. Gu A, Lu J, Wang W, Shi C, Han B, Yao M. Role of miR497 in VEGF-A-mediated cancer cell growth and invasion in non-small cell lung cancer. Int J Biochem Cell Biol. 2016; 70:118-125.

32. Huang C, Ma R, Yue J, Li N, Li Z, Qi D. MiR-497 Suppresses YAP1 and Inhibits Tumor Growth in NonSmall Cell Lung Cancer. Cell Physiol Biochem. 2015; 37:342-352.

33. Han Z, Zhang Y, Yang Q, Liu B, Wu J, Zhang Y, Yang C, Jiang Y. miR-497 and miR-34a retard lung cancer growth by co-inhibiting cyclin E1 (CCNE1). Oncotarget. 2015; 6:13149-13163. https://doi.org/10.18632/oncotarget.3693.

34. Zhao WY, Wang Y, An ZJ, Shi CG, Zhu GA, Wang B, Lu MY, Pan CK, Chen P. Downregulation of miR-497 promotes tumor growth and angiogenesis by targeting HDGF in non-small cell lung cancer. Biochem Biophys Res Commun. 2013; 435:466-471.

35. Zhu W, Zhu D, Lu S, Wang T, Wang J, Jiang B, Shu Y, Liu P. miR-497 modulates multidrug resistance of human cancer cell lines by targeting BCL2. Med Oncol. 2012; 29:384-391.

36. Zhan M, Qu Q, Wang G, Zhou H. Let-7c sensitizes acquired cisplatin-resistant A549 cells by targeting ABCC2 and BclXL. Die Pharmazie. 2013; 68:955-961.
37. Zang YS, Zhong YF, Fang Z, Li B, An J. MiR-155 inhibits the sensitivity of lung cancer cells to cisplatin via negative regulation of Apaf-1 expression. Cancer Gene Ther. 2012; 19:773-778.

38. Wang Q, Zhong M, Liu W, Li J, Huang J, Zheng L. Alterations of microRNAs in cisplatin-resistant human nonsmall cell lung cancer cells (A549/DDP). Exp Lung Res. 2011; 37:427-434.

39. Zhang H, Zhang H, Zhao M, Lv Z, Zhang X, Qin X, Wang H, Wang S, Su J, Lv X, Liu H, Du W, Zhou W, et al. MiR-138 inhibits tumor growth through repression of EZH2 in nonsmall cell lung cancer. Cell Physiol Biochem. 2013; 31:56-65.

40. Han LP, Fu T, Lin Y, Miao JL, Jiang QF. MicroRNA-138 negatively regulates non-small cell lung cancer cells through the interaction with cyclin D3. Tumor Biol. 2016; 37:291-298.

41. Ye XW, Yu H, Jin YK, Jing XT, Xu M, Wan ZF, Zhang XY. miR-138 inhibits proliferation by targeting 3-phosphoinositide-dependent protein kinase-1 in non-small cell lung cancer cells. Clin Respir J. 2015; 9:27-33.

42. Yang T, Li H, Thakur A, Chen T, Xue J, Li D, Chen M. FOXP4 modulates tumor growth and independently associates with miR-138 in non-small cell lung cancer cells. Tumor Biol. 2015; 36:8185-8191.

43. Li J, Wang Q, Wen R, Liang J, Zhong X, Yang W, Su D, Tang J. MiR-138 inhibits cell proliferation and reverses epithelial-mesenchymal transition in non-small cell lung cancer cells by targeting GIT1 and SEMA4C. J Cell Mol Med. 2015; 19:2793-2805.

44. Xiao L, Zhou H, Li XP, Chen J, Fang C, Mao CX, Cui JJ, Zhang W, Zhou HH, Yin JY, Liu ZQ. MicroRNA-138 acts as a tumor suppressor in non small cell lung cancer via targeting YAP1. Oncotarget. 2016; 7:40038-40046. https:// doi.org/10.18632/oncotarget.9480.

45. Tan Y, Hu H, Tan W, Jin L, Liu J, Zhou H. MicroRNA-138 inhibits migration and invasion of non-small cell lung cancer cells by targeting LIMK1. Mol Med Rep. 2016; 14:4422-4428.

46. Li H, Zhang P, Sun X, Sun Y, Shi C, Liu H, Liu X. MicroRNA-181a regulates epithelial-mesenchymal transition by targeting PTEN in drug-resistant lung adenocarcinoma cells. Int J Oncol. 2015; 47:1379-1392.

47. Bian HB, Pan X, Yang JS, Wang ZX, De W. Upregulation of microRNA-451 increases cisplatin sensitivity of non-small cell lung cancer cell line (A549). J Exp Clin Cancer Res. 2011; 30:20.

48. Cheng D, Xu Y, Sun C, He Z. MicroRNA-451 sensitizes lung cancer cells to cisplatin through regulation of Mcl-1. Mol Cell Biochem. 2016.

49. Zhou L, Qiu T, Xu J, Wang T, Wang J, Zhou X, Huang Z, Zhu W, Shu Y, Liu P. miR-135a/b modulate cisplatin resistance of human lung cancer cell line by targeting MCL1. Pathol Oncol Res. 2013; 19:677-683.

50. Xiang Q, Tang H, Yu J, Yin J, Yang X, Lei X. MicroRNA-98 sensitizes cisplatin-resistant human lung adenocarcinoma 
cells by up-regulation of HMGA2. Die Pharmazie. 2013; 68:274-281.

51. Yang G, Zhang X, Shi J. MiR-98 inhibits cell proliferation and invasion of non-small cell carcinoma lung cancer by targeting PAK1. Int J Clin Exp Med. 2015; 8:20135-20145.

52. Wei J, Gao W, Zhu CJ, Liu YQ, Mei Z, Cheng T, Shu YQ. Identification of plasma microRNA-21 as a biomarker for early detection and chemosensitivity of non-small cell lung cancer. Chin J Cancer. 2011; 30:407-414.

53. Lee JH, Voortman J, Dingemans AM, Voeller DM, Pham T, Wang Y, Giaccone G. MicroRNA expression and clinical outcome of small cell lung cancer. PLoS One. 2011; 6:e21300.

54. Yang Z, Fang S, Di Y, Ying W, Tan Y, Gu W. Modulation of NF-kappaB/miR-21/PTEN pathway sensitizes non-small cell lung cancer to cisplatin. PLoS One. 2015; 10:e0121547.

55. Qiu T, Zhou L, Wang T, Xu J, Wang J, Chen W, Zhou X, Huang Z, Zhu W, Shu Y, Liu P. miR-503 regulates the resistance of non-small cell lung cancer cells to cisplatin by targeting Bcl-2. Int J Mol Med. 2013; 32:593-598.

56. Li N, Zhang F, Li S, Zhou S. Epigenetic silencing of MicroRNA-503 regulates FANCA expression in non-small cell lung cancer cell. Biochem Biophys Res Commun. 2014; 444:611-616.

57. Sui C, Meng F, Li Y, Jiang Y. miR-148b reverses cisplatinresistance in non-small cell cancer cells via negatively regulating DNA (cytosine-5)-methyltransferase 1(DNMT1) expression. J Transl Med. 2015; 13:132.

58. Herman JG, Baylin SB. Gene silencing in cancer in association with promoter hypermethylation. N Engl J Med. 2003; 349:2042-2054.

59. Xiang Y, Ma N, Wang D, Zhang Y, Zhou J, Wu G, Zhao R, Huang H, Wang X, Qiao Y, Li F, Han D, Wang L, et al. MiR-152 and miR-185 co-contribute to ovarian cancer cells cisplatin sensitivity by targeting DNMT1 directly: a novel epigenetic therapy independent of decitabine. Oncogene. 2014; 33:378-386.

60. Lu L, Xuejin Z, Bo Z, Jun W, Zhang X. Synaptic acetylcholinesterase targeted by microRNA-212 functions asa tumor suppressor in non-small cell lung cancer. Int J Biochem Cell Biol. 2013; 45:2530-2540.

61. Donzelli S, Fontemaggi G, Fazi F, Di Agostino S, Padula F, Biagioni F, Muti P, Strano S, Blandino G. MicroRNA-128-2 targets the transcriptional repressor E2F5 enhancing mutant p53 gain of function. Cell Death Differ. 2012; 19:1038-1048.

62. Sun W, Ma Y, Chen P, Wang D. MicroRNA-10a silencing reverses cisplatin resistance in the A549/cisplatin human lung cancer cell line via the transforming growth factorbeta/Smad2/STAT3/STAT5 pathway. Mol Med Rep. 2015; 11:3854-3859.

63. Xie J, Yu F, Li D, Zhu X, Zhang X, Lv Z. MicroRNA-218 regulates cisplatin (DPP) chemosensitivity in non-small cell lung cancer by targeting RUNX2. Tumor Biol. 2016; 37:1197-1204.
64. Wu L, Pu X, Wang Q, Cao J, Xu F, Xu LI, Li K. miR-96 induces cisplatin chemoresistance in non-small cell lung cancer cells by downregulating SAMD9. Oncol Lett. 2016; 11:945-952.

65. Fu WF, Chen WB, Dai L, Yang GP, Jiang ZY, Pan L, Zhao J, Chen $\mathrm{G}$. Inhibition of miR-141 reverses cisplatin resistance in non-small cell lung cancer cells via upregulation of programmed cell death protein 4. Eur Rev Med Pharmacol Sci. 2016; 20:2565-2572.

66. Hao GJ, Hao HJ, Ding YH, Wen H, Li XF, Wang QR, Zhang BB. Suppression of EIF4G2 by miR-379 potentiates the cisplatin chemosensitivity in nonsmall cell lung cancer cells. FEBS Lett. 2017; 591:636-645.

67. Dong Z, Zhong Z, Yang L, Wang S, Gong Z. MicroRNA-31 inhibits cisplatin-induced apoptosis in non-small cell lung cancer cells by regulating the drug transporter ABCB9. Cancer Lett. 2014; 343:249-257.

68. Ma Y, Li X, Cheng S, Wei W, Li Y. MicroRNA-106a confers cisplatin resistance in non-small cell lung cancer A549 cells by targeting adenosine triphosphatase-binding cassette A1. Mol Med Rep. 2015; 11:625-632.

69. Pei K, Zhu JJ, Wang CE, Xie QL, Guo JY. MicroRNA185-5p modulates chemosensitivity of human non-small cell lung cancer to cisplatin via targeting ABCC1. Eur Rev Med Pharmacol Sci. 2016; 20:4697-4704.

70. Song L, Li Y, Li W, Wu S, Li Z. miR-495 enhances the sensitivity of non-small cell lung cancer cells to platinum by modulation of copper-transporting P-type adenosine triphosphatase A (ATP7A). J Cell Biochem. 2014; 115:1234-1242.

71. Chu H, Chen X, Wang H, Du Y, Wang Y, Zang W, Li P, Li J, Chang J, Zhao G, Zhang G. MiR-495 regulates proliferation and migration in NSCLC by targeting MTA3. Tumor Biol. 2014; 35:3487-3494.

72. Hwang-Verslues WW, Chang PH, Wei PC, Yang CY, Huang CK, Kuo WH, Shew JY, Chang KJ, Lee EY, Lee WH. miR-495 is upregulated by E12/E47 in breast cancer stem cells, and promotes oncogenesis and hypoxia resistance via downregulation of E-cadherin and REDD1. Oncogene. 2011; 30:2463-2474.

73. Jiang X, Huang H, Li Z, He C, Li Y, Chen P, Gurbuxani S, Arnovitz S, Hong GM, Price C, Ren H, Kunjamma RB, Neilly MB, et al. MiR-495 is a tumor-suppressor microRNA down-regulated in MLL-rearranged leukemia. Proc Natl Acad Sci U S A. 2012; 109:19397-19402.

74. Inoue $\mathrm{Y}$, Matsumoto H, Yamada S, Kawai K, Suemizu H, Gika M, Takanami I, Iwazaki M, Nakamura M. Association of ATP7A expression and in vitro sensitivity to cisplatin in non-small cell lung cancer. Oncol Lett. 2010; $1: 837-840$.

75. Kalayda GV, Wagner CH, Buss I, Reedijk J, Jaehde U. Altered localisation of the copper efflux transporters ATP7A and ATP7B associated with cisplatin resistance in human ovarian carcinoma cells. BMC Cancer. 2008; 8:175. 
76. Yoshizawa K, Nozaki S, Kitahara H, Ohara T, Kato K, Kawashiri S, Yamamoto E. Copper efflux transporter (ATP7B) contributes to the acquisition of cisplatinresistance in human oral squamous cell lines. Oncol Rep. 2007; 18:987-991.

77. Kuo MT, Chen HH, Song IS, Savaraj N, Ishikawa T. The roles of copper transporters in cisplatin resistance. Cancer Metastasis Rev. 2007; 26:71-83.

78. Liang N, Zhou X, Zhao M, Zhao D, Zhu Z, Li S, Yang H. Down-regulation of microRNA-26b modulates nonsmall cell lung cancer cells chemoresistance and migration through the association of PTEN. Acta Biochim Biophys Sin. 2015; 47:530-538.

79. Guo J, Feng Z, Huang Z, Wang H, Lu W. MicroRNA-217 functions as a tumour suppressor gene and correlates with cell resistance to cisplatin in lung cancer. Mol Cells. 2014; 37:664-671.

80. Chen QY, Jiao DM, Wang J, Hu H, Tang X, Chen J, Mou $\mathrm{H}, \mathrm{Lu}$ W. miR-206 regulates cisplatin resistance and EMT in human lung adenocarcinoma cells partly by targeting MET. Oncotarget. 2016; 7:24510-24526. https://doi. org/10.18632/oncotarget.8229.

81. Jiang Z, Yin J, Fu W, Mo Y, Pan Y, Dai L, Huang H, Li S, Zhao J. MiRNA 17 family regulates cisplatin-resistant and metastasis by targeting TGFbetaR2 in NSCLC. PLoS One. 2014; 9:e94639.

82. Li J, Wang Y, Song Y, Fu Z, Yu W. miR-27a regulates cisplatin resistance and metastasis by targeting RKIP in human lung adenocarcinoma cells. Mol Cancer. 2014; 13:193.

83. Li W, Wang W, Ding M, Zheng X, Ma S, Wang X. MiR1244 sensitizes the resistance of non-small cell lung cancer A549 cell to cisplatin. Cancer Cell Int. 2016; 16:30.

84. Ning FL, Wang F, Li ML, Yu ZS, Hao YZ, Chen SS. MicroRNA-182 modulates chemosensitivity of human non-small cell lung cancer to cisplatin by targeting PDCD4. Diagn Pathol. 2014; 9:143.

85. Huang X, Le QT, Giaccia AJ. MiR-210--micromanager of the hypoxia pathway. Trends Mol Med. 2010; 16:230-237.

86. Huang X, Ding L, Bennewith KL, Tong RT, Welford SM, Ang KK, Story M, Le QT, Giaccia AJ. Hypoxia-inducible mir-210 regulates normoxic gene expression involved in tumor initiation. Mol Cell. 2009; 35:856-867.

87. Malzkorn B, Wolter M, Liesenberg F, Grzendowski M, Stuhler $\mathrm{K}$, Meyer HE, Reifenberger G. Identification and functional characterization of microRNAs involved in the malignant progression of gliomas. Brain Pathol. 2010; 20:539-550.

88. Satzger I, Meier A, Alter M, Kapp A, Gutzmer R. Parameters predicting prognosis in melanoma sentinel nodes. J Clin Oncol. 2011; 29:3588-3590; author reply 3590-3581.

89. Greither T, Grochola LF, Udelnow A, Lautenschlager C, Wurl P, Taubert H. Elevated expression of microRNAs 155, 203, 210 and 222 in pancreatic tumors is associated with poorer survival. Int J Cancer. 2010; 126:73-80.
90. Yanaihara N, Caplen N, Bowman E, Seike M, Kumamoto K, Yi M, Stephens RM, Okamoto A, Yokota J, Tanaka T, Calin GA, Liu CG, Croce CM, Harris CC. Unique microRNA molecular profiles in lung cancer diagnosis and prognosis. Cancer Cell. 2006; 9:189-198.

91. Puissegur MP, Mazure NM, Bertero T, Pradelli L, Grosso S, Robbe-Sermesant K, Maurin T, Lebrigand K, Cardinaud B, Hofman V, Fourre S, Magnone V, Ricci JE, et al. miR-210 is overexpressed in late stages of lung cancer and mediates mitochondrial alterations associated with modulation of HIF-1 activity. Cell Death Differ. 2011; 18:465-478.

92. Grosso S, Doyen J, Parks SK, Bertero T, Paye A, Cardinaud B, Gounon P, Lacas-Gervais S, Noel A, Pouyssegur J, Barbry P, Mazure NM, Mari B. MiR-210 promotes a hypoxic phenotype and increases radioresistance in human lung cancer cell lines. Cell Death Dis. 2013; 4:e544.

93. Eilertsen M, Andersen S, Al-Saad S, Richardsen E, Stenvold H, Hald SM, Al-Shibli K, Donnem T, Busund LT, Bremnes RM. Positive prognostic impact of miR-210 in non-small cell lung cancer. Lung Cancer. 2014; 83:272-278.

94. Osugi J, Kimura Y, Owada Y, Inoue T, Watanabe Y, Yamaura T, Fukuhara M, Muto S, Okabe N, Matsumura Y, Hasegawa T, Yonechi A, Hoshino M, et al. Prognostic Impact of Hypoxia-Inducible miRNA-210 in Patients with Lung Adenocarcinoma. J Oncol. 2015; 2015:316745.

95. Ding G, Huang G, Liu H, Liang H, Ni Y, Ding Z, Ni G, Hua H. MiR-199a suppresses the hypoxia-induced proliferation of non-small cell lung cancer cells through targeting HIF1 $\alpha$. Mol Cell Biochem. 2013; 384:173-180.

96. Ding G, Huang G, Liu H, Liang H, Ni Y, Ding Z, Ni G, Hua H. MiR-199a suppresses the hypoxia-induced proliferation of non-small cell lung cancer cells through targeting HIF1 $\alpha$. Mol Cell Biochem. 2013; 384:173-180.

97. Mao G, Liu Y, Fang X, Liu Y, Fang L, Lin L, Liu X, Wang N. Tumor-derived microRNA-494 promotes angiogenesis in non-small cell lung cancer. Angiogenesis. 2015; 18:373-382.

98. He W, Li Y, Chen X, Lu L, Tang B, Wang Z, Pan Y, Cai S, $\mathrm{He} \mathrm{Y}, \mathrm{Ke}$ Z. miR-494 acts as an anti-oncogene in gastric carcinoma by targeting c-myc. Gastroenterol Hepatol. 2014; 29:1427-1434.

99. Cheng CW, Chen PM, Hsieh YH, Weng CC, Chang CW, Yao CC, Hu LY, Wu PE, Shen CY. Foxo3a-mediated overexpression of microRNA-622 suppresses tumor metastasis by repressing hypoxia-inducible factor-1alpha in ERKresponsive lung cancer. Oncotarget. 2015; 6:44222-44238. https://doi.org/10.18632/oncotarget.5826.

100. Li ZH, Zhang H, Yang ZG, Wen GQ, Cui YB, Shao GG. Prognostic significance of serum microRNA-210 levels in nonsmall-cell lung cancer. J Int Med Res. 2013; 41:1437-1444.

101. Yang Y, Liu L, Zhang Y, Guan H, Wu J, Zhu X, Yuan J, Li M. MiR-503 targets PI3K p85 and IKK-beta and suppresses progression of non-small cell lung cancer. Int $\mathrm{J}$ Cancer. 2014; 135:1531-1542. 
102. Liu L, Qu W, Zhong Z. Down-regulation of miR-503 expression predicate advanced mythological features and poor prognosis in patients with NSCLC. Int J Clin Exp Pathol. 2015; 8:5609-5613.

103. Cui EH, Li HJ, Hua F, Wang B, Mao W, Feng XR, Li JY, Wang X. Serum microRNA $125 \mathrm{~b}$ as a diagnostic or prognostic biomarker for advanced NSCLC patients receiving cisplatin-based chemotherapy. Acta Pharmacol Sin. 2013; 34:309-313.

104. Zhong KZ, Chen WW, Hu XY, Jiang AL, Zhao J. Clinicopathological and prognostic significance of microRNA-107 in human non small cell lung cancer. Int J Clin Exp Pathol. 2014; 7:4545-4551.

105. Gallardo E, Navarro A, Vinolas N, Marrades RM, Diaz T, Gel B, Quera A, Bandres E, Garcia-Foncillas J, Ramirez J, Monzo M. miR-34a as a prognostic marker of relapse in surgically resected non-small-cell lung cancer. Carcinogenesis. 2009; 30:1903-1909.

106. Li J, Guan J, Long X, Wang Y, Xiang X. mir-1-mediated paracrine effect of cancer-associated fibroblasts on lung cancer cell proliferation and chemoresistance. Oncol Rep. 2016; 35:3523-3531.

107. Wu Y, Crawford M, Mao Y, Lee RJ, Davis IC, Elton TS, Lee LJ, Nana-Sinkam SP. Therapeutic Delivery of MicroRNA29b by Cationic Lipoplexes for Lung Cancer. Mol Ther Nucleic Acids. 2013; 2:e84.

108. Wang X, Dong K, Gao P, Long M, Lin F, Weng Y, Ouyang Y, Ren J, Zhang H. microRNA-34a sensitizes lung cancer cell lines to DDP treatment independent of p53 status. Cancer Biother Radiopharm. 2013; 28:45-50.

109. Zhou DH, Wang X, Feng Q. EGCG enhances the efficacy of cisplatin by downregulating hsa-miR-98-5p in NSCLC A549 cells. Nutr Cancer. 2014; 66:636-644.

110. Su W, Mo Y, Wu F, Guo K, Li J, Luo Y, Ye H, Guo H, Li D, Yang Z. miR-135b reverses chemoresistance of non-small cell lung cancer cells by downregulation of FZD1. Biomed Pharmacother. 2016; 84:123-129.

111. Shen H, Wang L, Ge X, Jiang CF, Shi ZM, Li DM, Liu WT, Yu X, Shu YQ. MicroRNA-137 inhibits tumor growth and sensitizes chemosensitivity to paclitaxel and cisplatin in lung cancer. Oncotarget. 2016; 7:20728-20742. https://doi. org/10.18632/oncotarget.8011.

112. Perry MM, Williams AE, Tsitsiou E, Larner-Svensson HM, Lindsay MA. Divergent intracellular pathways regulate interleukin-1beta-induced miR-146a and miR$146 \mathrm{~b}$ expression and chemokine release in human alveolar epithelial cells. FEBS Lett. 2009; 583:3349-3355.

113. Shi L, Xu Z, Wu G, Chen X, Huang Y, Wang Y, Jiang W, Ke B. Up-regulation of miR-146a increases the sensitivity of non-small cell lung cancer to DDP by downregulating cyclin J. BMC Cancer. 2017; 17:138.

114. Wang X, Chen X, Meng Q, Jing H, Lu H, Yang Y, Cai L, Zhao Y. MiR-181b regulates cisplatin chemosensitivity and metastasis by targeting TGFbetaR1/Smad signaling pathway in NSCLC. Sci Rep. 2015; 5:17618.
115. Li Q, Yang Z, Chen M, Liu Y. Downregulation of microRNA-196a enhances the sensitivity of non-small cell lung cancer cells to cisplatin treatment. Int J Mol Med. 2016; 37:1067-1074.

116. Wang H, Zhu LJ, Yang YC, Wang ZX, Wang R. MiR224 promotes the chemoresistance of human lung adenocarcinoma cells to cisplatin via regulating $\mathrm{G} / \mathrm{S}$ transition and apoptosis by targeting p21(WAF1/CIP1). Br J Cancer. 2014; 111:339-354.

117. Chen L, Kong G, Zhang C, Dong H, Yang C, Song G, Guo C, Wang L, Yu H. MicroRNA-432 functions as a tumor suppressor gene through targeting E2F3 and AXL in lung adenocarcinoma. Oncotarget. 2016; 7:20041-20053. https:// doi.org/10.18632/oncotarget.7884.

118. Pang W, Tian X, Bai F, Han R, Wang J, Shen H, Zhang X, Liu Y, Yan X, Jiang F, Xing L. Pim-1 kinase is a target of miR-486-5p and eukaryotic translation initiation factor 4E, and plays a critical role in lung cancer. Mol Cancer. 2014; 13:240.

119. Xu L, Huang Y, Chen D, He J, Zhu W, Zhang Y, Liu X. Downregulation of miR-21 increases cisplatin sensitivity of non-small-cell lung cancer. Cancer Genet. 2014; 207:214-220.

120. Dong Z, Ren L, Lin L, Li J, Huang Y, Li J. Effect of microRNA-21 on multidrug resistance reversal in A549/ DDP human lung cancer cells. Mol Med Rep. 2015; 11:682-690.

121. Yang Y, Zhang P, Zhao Y, Yang J, Jiang G, Fan J. Decreased MicroRNA-26a expression causes cisplatin resistance in human non-small cell lung cancer. Cancer Biol Ther. 2016; 17:515-525.

122. Su TJ, Ku WH, Chen HY, Hsu YC, Hong QS, Chang GC, Yu SL, Chen JJ. Oncogenic miR-137 contributes to cisplatin resistance via repressing CASP3 in lung adenocarcinoma. Am J Cancer Res. 2016; 6:1317-1330.

123. Zhu W, Shan X, Wang T, Shu Y, Liu P. miR-181b modulates multidrug resistance by targeting BCL2 in human cancer cell lines. Int J Cancer. 2010; 127:2520-2529.

124. Li JH, Luo N, Zhong MZ, Xiao ZQ, Wang JX, Yao XY, Peng Y, Cao J. Inhibition of microRNA-196a might reverse cisplatin resistance of A549/DDP non-small-cell lung cancer cell line. Tumour Biol. 2016; 37:2387-2394.

125. Zhu W, Xu H, Zhu D, Zhi H, Wang T, Wang J, Jiang B, Shu Y, Liu P. miR-200bc/429 cluster modulates multidrug resistance of human cancer cell lines by targeting BCL2 and XIAP. Cancer Chemother Pharmacol. 2012; 69:723-731.

126. Zhang X, Zhu J, Xing R, Tie Y, Fu H, Zheng X, Yu B. miR513a-3p sensitizes human lung adenocarcinoma cells to chemotherapy by targeting GSTP1. Lung Cancer. 2012; $77: 488-494$.

127. Zhao J, Fu W, Liao H, Dai L, Jiang Z, Pan Y, Huang H, Mo Y, Li S, Yang G, Yin J. The regulatory and predictive functions of miR-17 and miR-92 families on cisplatin resistance of non-small cell lung cancer. BMC Cancer. 2015; 15:731. 
128. Xu S, Huang H, Chen YN, Deng YT, Zhang B, Xiong XD, Yuan Y, Zhu Y, Huang H, Xie L, Liu X. DNA damage responsive miR-33b-3p promoted lung cancer cells survival and cisplatin resistance by targeting $21 \mathrm{WAF} 1 / \mathrm{CIP} 1$. Cell Cycle. 2016; 15:2920-2930.

129. Zhao Z, Zhang L, Yao Q, Tao Z. miR-15b regulates cisplatin resistance and metastasis by targeting PEBP4 in human lung adenocarcinoma cells. Cancer Gene Ther. 2015; 22:108-114.

130. Chan YT, Lin YC, Lin RJ, Kuo HH, Thang WC, Chiu KP, $\mathrm{Yu}$ AL. Concordant and discordant regulation of target genes by miR-31 and its isoforms. PLoS One. 2013; 8:e58169.

131. Yu G, Zhong N, Chen G, Huang B, Wu S. Downregulation of PEBP4, a target of miR-34a, sensitizes drug-resistant lung cancer cells. Tumour Biol. T2014; 35:10341-10349.

132. Jing XG, Chen TF, Huang C, Wang H, An L, Cheng Z, Zhang GJ. MiR-15a expression analysis in nonsmall cell lung cancer A549 cells under local hypoxia microenvironment. Eur Rev Med Pharmocol Sci. 2017; 21:2069-2074.

133. Taguchi A, Yanagisawa K, Tanaka M, Cao K, Matsuyama Y, Goto H, Takahashi T. Identification of hypoxia-inducible factor-1 alpha as a novel target for miR-17-92 microRNA cluster. Cancer Res. 2008; 68:5540-5545.

134. Akagi I, Okayama H, Schetter AJ, Robles AI, Kohno T, Bowman ED, Kazandjian D, Welsh JA, Oue N, Saito M, Miyashita M, Uchida E, Takizawa T, et al. Combination of protein coding and noncoding gene expression as a robust prognostic classifier in stage I lung adenocarcinoma. Cancer Res. 2013; 73:3821-3832.

135. Haigl B, Vanas V, Setinek U, Hegedus B, Gsur A, Sutterluty-Fall H. Expression of microRNA-21 in non-small cell lung cancer tissue increases with disease progression and is likely caused by growth conditional changes during malignant transformation. Int J Oncol. 2014; 44:1325-1334.

136. Jiang S, Wang R, Yan H, Jin L, Dou X, Chen D. MicroRNA-21 modulates radiation resistance through upregulation of hypoxia-inducible factor-1alpha-promoted glycolysis in non-small cell lung cancer cells. Mol Med Rep. 2016; 13:4101-4107.

137. Hsu YL, Hung JY, Chang WA, Lin YS, Pan YC, Tsai PH, Wu CY, Kuo PL. Hypoxic lung cancer-secreted exosomal miR-23a increased angiogenesis and vascular permeability by targeting prolyl hydroxylase and tight junction protein ZO-1. Oncogene. 2017.
138. Wang L, Zhang LF, Wu J, Xu SJ, Xu YY, Li D, Lou JT, Liu MF. IL-1 $\beta$-mediated repression of microRNA-101 is crucial for inflammation-promoted lung tumorigenesis. Cancer Res. 2014; 74:4720-4730.

139. He J, Qian X, Carpenter R, Xu Q, Wang L, Qi Y, Wang ZX, Liu LZ, Jiang BH. Repression of miR-143 mediates $\mathrm{Cr}$ (VI)-induced tumor angiogenesis via IGF-IR/IRS1/ERK/ IL-8 pathway. Toxicol Sci. 2013; 134:26-38.

140. Babar IA, Czochor J, Steinmetz A, Weidhaas JB, Glazer PM, Slack FJ. Inhibition of hypoxia-induced miR-155 radiosensitizes hypoxic lung cancer cells. Cancer Biol Ther. 2011; 12:908-914.

141. Zhao J, Qiao CR, Ding Z, Sheng YL, Li XN, Yang Y, Zhu DY, Zhang CY, Liu DL, Wu K, Zhao S. A novel pathway in NSCLC cells: miR191, targeting NFIA, is induced by chronic hypoxia, and promotes cell proliferation and migration. Mol Med Rep. 2017; 15:1319-1325.

142. Puissegur M, Mazure N, Bertero T, Pradelli L, Grosso S, Robbe-Sermesant K, Maurin T, Lebrigand K, Cardinaud B, Hofman V, Fourre S, Magnone V, Ricci J, et al. miR-210 is overexpressed in late stages of lung cancer and mediates mitochondrial alterations associated with modulation of HIF-1 activity. Cell Death Differ. 2011; 18:467-478.

143. Noman MZ, Buart S, Romero P, Ketari S, Janji B, Mari B, Mami-Chouaib F, Chouaib S. Hypoxia-inducible miR210 regulates the susceptibility of tumor cells to lysis by cytotoxic T cells. Cancer Res. 2012; 72:4629-4641.

144. Wu D, Chen B, Cui F, He X, Wang W, Wang M. Hypoxiainduced microRNA-301b regulates apoptosis by targeting Bim in lung cancer. Cell Prolif. 2016.

145. Cha ST, Chen PS, Johansson G, Chu CY, Wang MY, Jeng YM, Yu SL, Chen JS, Chang KJ, Jee SH, Tan CT, Lin MT, Kuo ML. MicroRNA-519c suppresses hypoxia-inducible factor-1alpha expression and tumor angiogenesis. Cancer Res. 2010; 70:2675-2685.

146. Ma Y, Feng J, Xing X, Zhou B, Li S, Zhang W, Jiang J, Zhang J, Qiao Z, Sun L, Ma Z, Kong R. miR-1908 Overexpression Inhibits Proliferation, Changing Akt Activity and p53 Expression in Hypoxic NSCLC Cells. Oncol Res. 2016; 24:9-15. 